\title{
EL SOPORTE IDEOLógICO DE LA INSURREcción CARLISTa
}

por

\section{PEDRO RÚJULA LóPEZ}

Universidad de Zaragoza

RESUMEN: La guerra civil carlista (1833-1840) fue un momento clave en el largo proceso de formación del discurso contrarrevolucionario en España cuyos onigenes se remontan a la reacción antililustrada de la segunda mitad del siglo XVII. La distancia existente entre la base social del movimiento y los cuadros dirigentes de la insurrección carlista determinó una fractura entre la ideología de la que ambos eran participes. Mientras la de la base se redujo a una recreación del conjunto de pautas de conducta, de las relaciones de poder y de la cultura heredadas del Antiguo Régimen, la ideología de la élite evolucionó con el tiempo manteniendo una relación dialéctica con la revolución. El resultado fue un entramado de términos, ideas y conceptos que configuran el discurso político de la contrarrevolución española que se analiza en este articulo.

PALABRAS CLAVE. Siglo xIx. I Guerra Carlista. Guerras carlistas. Carlismo. Ideologia Contrarrevolucionarla. Ilustración. Revoluclón. Prensa. Cultura. España. Aragón. Valencia. Cataluña. Cabrera.

ABSTRACT: The carlist civil war (1833-1840) was a key moment in the long process of making of the counterrevolutionary discourse in Spain whose originsback to the anti-enlightenment reaction in the second half of the eighteen century. The gap between the rank-and-file of the mouvement and the staff of the carlist insurrection produced a break in the common ideology. The ideology of the basis was a remake of the old patterns of conduct, power relations and the cultural heritage of Ancien Regime. Meanwhite, the elite's ideology chaged in a dialectical relation with the revolution. The result was a complex of terms, ideas and concepts shaping the political discourse of the spanish counterrevolution analized the present article.

KeY words: 19 Century. First Carlist war. Carlists Wars. Carlism. Ideology. Counterrevolution. Enlightenment. Revolution. Press. Culture. Spałn. aragón. Valencia. Catalonia. Cabrera.

Hisponia, LV]1/1, núm. 195 (1997) 213-265 
Uno de los elementos más significativos que se desprende de los estudios recientes sobre el apoyo social al carlismo durante la guerra civil de 18331840 es la naturaleza dual del movimiento '. Se perfila en ellos, de un lado, una base social compuesta de campesinos y artesanos que nutre el movimiento numéricamente y le proporciona su arraigo con la geografía del conflicto a través de su vinculación directa con la población, la economía y el universo mental del que surge el enfrentamiento. Y, por otra parte, unos cuadros dirigentes que aportan al movimiento su proyecto político contrarrevolucionario y una cualificación en los ámbitos de la administración, el ejército o la iglesia que les permite articular toda la potencia del descontento popular en forma de insurrección contra el proyecto liberal.

Un movimiento social que posee una diferenciación tan marcada entre base social y cuadros dirigentes tiene muchas probabilidades de verse afectado por una fractura significativa entre la ideología de uno y otro de sus componentes. Así ocurre en el caso del carlismo aragonés-valenciano, en el que no puede hablarse de una ideología compacta que articule globalmente el movimiento comprendiendo en su discurso, al tiempo que a los dirigentes, al resto de sus integrantes. Podría interpretarse que se trata de un mismo soporte ideológico al que accedían en distintos niveles los combatientes carlistas según su interés y sus capacidades, una simple cuestión de grado en la misma escala ideológica, pero la cuestión no es tan sencilla. Lo que diferencia la ideología de la base del movimiento de la de sus dirigentes está en que poseen génesis diversas y se establecen sobre distintas plataformas mentales. Sucede, en el caso de los campesinos, que participan de una ideología hegemónica durante el Antiguo Régimen porque están inmersos en ella y en sus dinámicas sociales y económicas sin siquiera una sola posibilidad de eludirla. Es la ideologia implicita que todo comportamiento social lleva consigo, pero que, en el caso de las clases populares, viene alimentada por la práctica cotidiana y un lento y pesado sedimento colectivo que constituye su universo cultural ${ }^{2}$. En el caso de la base del carlismo, la ideología implícita en su actividad resume el modo de entender el mundo interiorizado y experimentado durante siglos bajo la monarquía absoluta.

La circunstancia en la que se encuentran los cuadros dirigentes es otra. Participan y reproducen comportamientos consolidados durante el Antiguo Régi-

I Sobre Cataluña Anguera, Pere, Déu, Rei i Fam. El primer carlisme a Calalunya, Publicacións de L'Abadia de Montserrat, Barcelona, 1995, cap. III y SANTIRSO, Manuel, Revolución liberal y guerra civil en Cataluña (1933-1940), Tesis doctoral, LIAB, Barcelona, 1994, págs. 678-679, y en Aragón Rújula, Pedro, Rebeldía campesina y guerra civil en Aragón 1821-1840, Universidad de Zaragoza, 1994, cap. 6.

2 George Rudé sentala la existencia de un elemento tradicional, «inherente», basado uen la experiencia directa, la tradición oral o la memoria colectiva en lugar de ser algo que se aprende escuchando sermones o discursos o leyendo librosm. Revuelta popular y conciencia de clase, Critica, Barcelona, 1981, pág. 34. También Jean Sarrailh se refiere a la importancia que tiene el peso de la rutina en la rerproducción ideológica del Antiguo Régimen. La España ilustrada de la segunda mitad del siglo xVIl, Fondo de Cultura Económica, Mexico, 1957, pág. 37.

Hispania, LVIl/1, núm. 195 (1997) 213-26S 
men, pero ésta no es toda su ideología, apenas constituye una parte, la menos característica, de sus aportes ideológicos. Más cercanos a la cultura letrada y obligados por sus responsabilidades organizativas a manifestar en público sus ideas políticas, puede afirmarse que poseen una ideología explícita. Esto supone una abstracción política de los hechos, una estructuración de las ideas, una justificación de sus posturas y el desarrollo de un razonamiento que dé coherencia a todo ello. Y un ejercicio así no procede de una vaga tradición monárquica, sino que tiene un precedente mucho más concreto y cercano cuando la monarquía puso a trabajar a sus ideólogos para suministrar argumentos que contrarrestaran la producción filosófica que durante el siglo xviI comenzó a cuestionar algunos de los pilares básicos sobre los que había establecido su poder. Es por esto, porque la circunstancia de la monarquía absoluta amenazada por corrientes renovadoras no era nueva, por lo que el carlismo se inserta en la línea ideológica consolidada en la segunda mitad del siglo anterior por la reacción antiilustrada.

Así, mientras que la base ideológica de los combatientes carlistas se circunscribe al ámbito genérico de la monarquía absoluta, la raíz intelectual de los cuadros dirigentes se encuentra en la reacción antiilustrada del siglo xVIII ${ }^{3}$.

\section{LA REPRODUCCIÓN DE UN RÉGIMEN}

Las clases populares, y destacadamente el campesino del Antiguo Régimen, participaban de la ideología del régimen político en el que vivían. No era una actitud voluntaria, ni una opción entre otras, se trataba simplemente del único comportamiento posible. Sin embargo, la ideología implícita que conllevaba este modo de actuar contribuja de manera decisiva a la reproducción del régimen, produciéndose este efecto tan sólo con la práctica cotidiana de las pautas establecidas por la monarquía absoluta. El simple hecho de pagar con razonable puntualidad las rentas señoriales, satisfacer las exigencias fiscales, rendir cuentas del diezmo o cumplir con los oficios religiosos frente a la sociedad y a las instituciones servía para reproducir el régimen político absoluto tal y como estaba configurado. Lo decía Braulio Foz con gran agudeza en 1840:

...en otro tiempo sólo era justa la causa de los reyes; o más bien no se entendía que en una nación pudiera haber otra. Servir al rey, defender al rey, real servicio y otras locuciones y aún proverbios, demuestra que lo eran todo los reyes y sólo los reyes. Los reyes por su parte cuidaban mucho de que se cofundiese su causa con la de la nación, de que la nación no se entendiese nunca sin ellos, de que ni la paz ni la guerra tuviesen otra idea o concepto que la conveniencia o no al rey; y siempre el nombre del rey era el que se pronunciaba, el que los significaba y lo representaba todo 4 .

${ }^{3}$ Deseo manifestar mi agradecimiento al catedrático Juan José Carreras Ares cuyos comentarios y sugerencias me han proporcionado toda una perspectiva sobre el objeto de este artículo

${ }_{4}$ "La justa causa" articulo publicado en El Eco de Aragón, núm. 665, 12 de septiembre de 1840.

Hispania, LV11/1, núm. 195 (1997) 213-265 
La figura del rey como Padre de todos sus vasallos es una de las imágenes del poder más permanentes entre las clases populares y de las que mayor influencia han tenido en la perpetuación entre éstas de una imagen dulce del Antiguo Régimen consolidada durante el largo tiempo en el que su supremacía fue indiscutida. El fenómeno era comprendido en la época. Como puede leerse en la prensa zaragozana, existía la conciencia de que «el despotismo de trescientos años nos ha hecho confundir la verdadera personalidad realn. La aceptación bastante generalizada de una imagen paternalista del régimen permitió encarnar en el monarca la idea de ser él quien tomaba todas las decisiones del Estado. «Si en las órdenes, decretos, pragmáticas y toda esa multitud de providencias que el rey daba, veíamos al fin el nombre de una persona a quién iban dirigidas, suponíamos más bien que era ésta la encargada de comunicarlas, y hacer que se ejecutasen voluntades ajenas". Sin embargo no era responsable de las consecuencias que el ejercicio del poder tuviera aparejadas ya que en la misma imagen estaba contenida la idea de completa bondad de sus actuaciones ${ }^{5}$.

Aparecía el rey antes como el todo; como el ser que se informaba, que buscaba noticias, que atendía al bien de los súbditos, y que decidía acerca de los medios más a propósito para hacerlos felices. Era también el hombre que arrastrado por preocupaciones, o engañado por cortesanos aduladores, servía de instrumento a las miserables pasiones de la canalla que le rodeaba; y por consiguiente todo el mal que el pueblo sufría se refería al rey porque se pensaba, y con exactitud, que si el hubiera querido o sabido, los habría arrojado de su inmediación; y rodeándose de hombres de bien y de sabiduría, habría procurado el bienestar de sus súbditos. Todo el bien, pues, o el mal se refería al rey; y por consiguiente ni se apreciaban los talentos de los ministros, ni se le eximía del anatema que lanzan todos los hombres sobre los que creen perjudicarles ${ }^{6}$.

El liberalismo trató de incidir sobre esta realidad y transformarla introduciendo un modelo de Estado alternativo a ése que todos conocían y en medio del cual siempre habían vivido. No significaba la sustitución inmediata, únicamente la introducción de un segundo elemento que permitiera la disyuntiva; la ingente labor de atraer apoyos para ese proyecto estaba todavía por realizar. En distintas coyunturas políticas, favorables unas, hostiles otras, la difusión del mensaje liberal fue progresando y calando en algunos sectores de la sociedad. Las ciudades fueron los primeros focos que manifestaron su apoyo al nuevo proyecto: apoyo a la milicia nacional, sublevaciones, pronunciamientos, constitución de juntas, etc., toda una serie de signos que delataban la revolución burguesa en marcha, se pusieron de manifiesto en las ciudades.

5 Ha sido Jaume Torras quien ha sabido mostrar los verdaderos matices que puede tener la rejvindicación de esta imagen del rey que se producen con ocasión de las revueltas campesinas. Liberalismo y rebeldía campesina 1820-1823, Ariel, Barcelona, 1976, págs. 16-17.

6 Diario Constitucional de Zaragoza, núm. 34,3 de febrero de 1840 . Sobre el mismo aspecto también en el núm. 39, 8 de fébrero del mismo diario.

Hispania, LVIJ/1, nüm. 195 (1997) 213-265 
Mientras tanto amplias zonas situadas en el ámbito rural eran refractarias al mensaje liberal. Las condiciones eran otras y una conjunción de razones de conveniencia del nuevo proyecto con otras sobre la lentitud con que el mensaje penetraba en sociedades menos permeables a las influencias externas, determinaron que la base social que participó en el proceso contrarrevolucionario español pueda ser encuadrada ideológicamente entre aquella gran masa rural que hasta ese momento había reproducido las pautas culturales del Antiguo Régimen. Una suerte de ideología implícita que bien podía ser excitada y reclamada por parte de las élites contrarrevolucionarias.

La existencia de una masa campesina que participaba de la ideología que había suministrado durante largo tiempo la monarquía absoluta determinó las características ideológicas de las bases carlistas.

a) Una ideología básica, expresada mediante proposiciones elementales y genéricas que giran en torno a dos ejes centrales: la monarquía absoluta y la Religión Católica. El grito «viva el Altar y el Trono» recorre sin variación el Trienio liberal como expresión del mensaje contrarrevolucionario, atraviesa la década posterior instrumentalizado por Fernando VII como pieza central de su proyecto reaccionario posterior a $1823^{7}$ y desemboca diez años después, al comienzo de la guerra civil, sin haberse modificado en lo fundamental. Y durante la primera fase de la guerra constituye la base del primitivo ideario contrarrevolucionario ${ }^{8}$. Se añaden manifestaciones de adhesión al pretendiente, circunstancia que no existía con anterioridad, expresadas mediante voces de "Viva Carlos V" ${ }^{9}$. Pero cuando al final de la guerra, en el contexto de la transacción, cambian las circunstancias de los carlistas, modifican la orientación de sus fidelidades hacia otro punto más oportuno, como reflejan algunas expresiones de "Muera Carlos V y viva Cabrera" sobre los muros de Chulilla escritas por los propios carlistas ${ }^{10}$. Esto muestra cómo su concepción política se articula en torno a un tronco básico, sin apenas variaciones en el tiempo. Y, por otro lado el profundo utilitarismo que posee la política para la base de combatientes rebeldes que cambian en sus proposiciones centrales cuando éstas ya no responden a sus expectativas. Aquí reside otro de sus componentes importantes.

b) Utilitarismo. La ideología expresa de la base insurreccional es fundamentalmente utilitaria. Difícilmente pueden hallarse ejemplos que estén exentos de esta vertiente pragmática. Si no es en el trance de obtener algo -suministros, quintos, cohesión interna frente al enemigo, etc.- no existe la necesidad de expresarse en términos políticos. Inmersos de continuo en el

7 Vid. Rưsula, Pedro, Rebeldía campesina y guerra civil en Aragón.,, cap. 3.

8 En Rebeldía campesina y primer carlismo en Aragón (1833.1835), D.G.A., Zaragoza, 1995, cap. $V$ analizábamos el esquematismo y fundamento utilitario de la ideologia carlista durante los dos primeros antos de guerra.

9 Sirva de ejemplo Belchite donde fueron pronunciadas «voces alarmantes y vivas a Carlos Quintow durante la alteración del orden que se produjo el primero de julio de 1837. Zaragoza, parte semanal de seguridad pública, ADPZ, Vig. XV 1032.

10 Diario Constitucional de Zaragoza, núm. 281, 8 de octubre de 1839. 
contexto de la guerra los combatientes carlistas instrumentalizaron los segmentos más universales del discurso contrarrevolucionario para dar respaldo a las acciones concretas de carácter económico o militar.

c) Fragilidad de la justificación abstracta de los motivos que llevaron a la insurrección. El campesinado se encontraba incómodo teniendo que hacer uso de justificaciones abstractas de su actitud; éstas apenas significaban un tenue barniz en su interpretación de la realidad. La suya era una ideología que se afirmaba por los hechos y tan pronto como tuvo hechos que justificaran su actitud se abandonó a ellos como argumento rechazando otras abstracciones. La guerra se convirtio muy pronto en argumento para la guerra. Esto lo comprendió muy bien Cabrera que fomentó las adhesiones no en torno a ideas tanto como a hechos en los que todos habían participado, o por los que todos se habían indignado, pero que nada tenían que ver con las justificaciones originarias.

Voluntarios: nuestros enemigos, que lo son también de la patria, nos darán el triunfo, porque ya veis como se aumentan nuestras filas desde las asonadas de Madrid, Zaragoza, Barcelona, Murcia y otros puntos. Alli asesinan a la faz del día, se rebelan contra las autoridades, saquean las casas, entran en los templos, y dentro del coro, matan a los religiosos indefensos, como ha sucedido en Zaragoza; destierran a vuestros padres, esposas e hijos, fusilan sin formación de causa, y se cometen todas esas iniquidades que publican cada día los periódicos de la revolución. Los que se llaman justos y benéficos obran así, sin que se castiguen tantos y tan atroces crímenes. Y aún se atreven a llamamos a nosotros forajidos y facciosos. Ellos sí que son facciosos, porque cada día quieren un gobierno; ellos si que son sanguinarios al publicar sus bandos y decretos como los de Llauder, Nogueras, Alvarez, Lorenzo, Rodil y otros, dignos de los Herodes o Nerones. No os fieis de sus palabras, voluntarios, ya veis la suerte que han tenido los que se acogieron a varios indultos, que cuando mas tranquilos vivían, fueron presos los mozos y casados que habian figurado entre nosotros como oficiales en el Bajo Aragón y Maestrazgo, y con muy pocas excepciones los mozos fueron destinados a los cuerpos de La Habana, y los demás a los presidios de Cádiz, Cartagena y Alicante. ¿Y qué ha conseguido con esto la revolución? Aumentar nuestra filas, como veis suceder todos los días. Pronto tendremos un ejército, si nuestros enemigos continúan así, y pronto nuestro soberano don Carlos V se sentară ел el trono de sus mayores. Valor, pues, y constancia, espera de vosotros quién nunca os abandonará y es vuestro compañero ${ }^{1 !}$.

No hay grandes principios, ni formulaciones de gran retórica, se trata de un mensaje directo y eficaz apoyado sobre lo más concreto de la guerra que justifica por sí misma la acción y en la utilización, siempre efectiva, de los muanismos de respuesta frente a cualquier operación exterior contra lo propio. Esta es una muestra de lo poco importantes que podían ser para los campesinos las justificaciones abstractas del movimiento insurreccional en el que estaban embarcados.

d) Si existía una vía por la que podían penetrar en el campesinado estos argumentos abstractos para la insurrección, era a través de los clérigos, seña-

11 Cabrera, junio de 1835, reproducido por PIRALA, Antonio, Historia de la guerra civil y de los partidos liberal y carlista. Turner/Historia 16, Madrid 1984, vol. Il, pág. 305.

Hikpania, LVI/t, aน́m. 195 (1997) 213-265 
ladamente los párrocos y los predicadores. Esta había sido la vía tradicional de penetración de la cultura «letrada" en las comunidades rurales y durante la primera guerra carlista siguió siendo una fórmula eficaz para provocar la insurrección por razón de "principios" ideológicos. Así lo comprendió el Estado liberal que trató de convertir a los eclesiásticos en medio para transmitir su mensaje político. Pero lo que no pudo impedir es que siguiera reproduciéndose el mensaje tradicional en los mismos términos desde esta posición privilegiada. Es el propio Nogueras quien en $\mathbf{1 8 3 5}$ llamaba la atención sobre los efectos de las doctrinas del clero y la presión de éste sobre la sociedad afirmando que «engañados unos, por las falsas doctrinas de los malos eclesiásticos, e incitados otros por sus mujeres y familias, han corrido a engrosar las filas de forajidos que despedazan la patria» 12.

En definitiva, la base social del carlismo poseía una ideología implícita que puede encuadrarse en los parámetros genéricos del Antiguo Régimen, consecuencia directa de sucesivas generaciones reproduciendo a la monarquía absoluta mediante el ejercicio cotidiano del rol de vasallo. Una ideología que el liberalismo no puede sustituir con la suficiente rapidez durante el proceso de revolución liberal como para impedir que fuera empleada por la contrarrevolución en su beneficio. Ya durante la guerra civil, cuando esta ideología se manifestó, lo hizo mostrando su constitución básica y elemental, profundamente utilitaria y que no tardó en pasar a un segundo plano para dar primacía a la guerra misma, a los hechos recién acontecidos, como justificación de la propia guerra. De este modo, la ideología como elaboración abstracta de contenidos políticos, apenas tiene incidencia en la justificación de porqué la base social se incorpora a la insurrección.

\section{EL MOMENTO DECISIVO DE LA REACCIÓN ANTIILUSTRADA}

El caso de la ideología de la que participan los cuadros dirigentes es muy distinto. Si bien puede encuadrarse entre las concepciones políticas originadas en el contexto del Antiguo Regimen, su genesis concreta se circunscribe al marco de la reacción antiilustrada que se produjo en España en la segunda mitad del siglo XVIII ${ }^{13}$. Ahí debe situarse el arranque de muchas de las ideas que constituirán con el tiempo la base de la argumentación contrarrevolucionaria. Es un largo recorrido, en el que cambian las posiciones y las circunstancias de los protagonistas, el que hay desde las primeras críticas al pensamiento ilustrado que reelaboradas como argumentos contra la Revolu-

12 Alcañiz, 9 de septiembre de 1835, Boletín Oficial de la Provincia de Teruel, núm. 77, 25 de septiembre de 1835 .

13 Roberto Fernández distingue muy acertadamente entre «el pensamiento absolutista tradicional», al que nos estamos refiriendo, $y$ «el absolutismo ilustrado», España en el siglo xvIII. Honenaje a Pierre Vilar, Crítica, Barcelona, 1985, pág. 49. Pero hay que tener en cuenta que, a medida que éste último se desarrolia, el primero se rearma progresivamente en una polémica antijlustrada constante.

Hispaniat. LVll/I, แúm. 195 (1997) 213-265 
ción francesa van a llegar hasta la década de los años 30 del siglo XIX para respaldar ideológicamente al carlismo. Por ello conviene trazar brevemente este trayecto identificando tres etapas en el proceso de formación y desarrollo del discurso contrarrevolucionario que alimenta ideológicamente al carlismo.

a) Desde mediados del siglo xVII hasta 1789. Esta primera fase se caracteriza por que el combate se desarrolla mayoritariamente en el plano ideológico. Desde mediados del siglo xviI las ideas de la rlustración fueron penetrando en España de forma irregular pero constante a pesar de las dificultades legales. El índice de libros prohibidos engrosó de día en día llevando a su seno a todos los clásicos franceses de las luces dieciochescas, desde la L'Encyclopédie hasta Rousseau, pasando por Voltaire o por Montesquieu. Las ideas ilustradas, mejor o peor encubiertas, encontraron camino para desarrollarse en un medio hostil a través de dos vías: las Sociedades Económicas y la prensa. El combate de las doctrinas de los philosophes no destacó en el plano del debate intelectual entre las ideas tradicionales y las nuevas teorías, sino que alcanzó sus mayores éxitos en el plano físico, es decir, impidiendo la traducción de estas obras al castellano o prohibiendo su circulación. Entre los que tomaron el camino de refutar las ideas de los filósofos ilustrados ${ }^{14}$ destacaron el fraile jerónimo Fernando de Zevallos - La falsa filosofía o el ateísmo, deísno, materialismo y demás nuevas sectas convencidas de crimen de estado contra los soberanos is_-, el poeta Juan Pablo Forner -Discursos filosóficos del hombre ${ }^{16}$ - Antonio Pérez y López -Principios del orden esencial de la naturaleza establecidos por fundamentos de la moral y por pruebas de la religión: Nuevo sistema filosófico ${ }^{17}$ - o Vicente Fernández Valcarce, -Desengaños filosóficos, que en obsequio de la verdad, de la religión y de la patria da al público... ${ }^{18}$ - . Aunque es de reseñar que las traducciones de los apologistas católicos franceses -Olmer Joly de Fleury, Claude Fraçois Nonnotte o LouisAntoine Caraccioli- fueron precursoras y gozaron de gran popularidad ${ }^{19}$. La persecución de las nuevas ideas quedó en manos de la Inquisición que tenía control sobre todo impreso que veía la luz en el país y además se ocupaba de confeccionar el índice de libros prohibidos.

b) Entre 1789 y 1812. Como consecuencia de las jornadas revolucionarias de julio de 1789 la contrarrevolución se manifestó políticamente abandonando el paraíso de ideas en el que hasta el momento se había desarrollado. Floridablanca, conmocionado por los acontecimientos franceses optó por

14 En torno a esta producción de obras escritas en España en el marco concreto de la reacción antiilustrada véase HERRERo, Javier, Los origenes del pensamiento reaccionario español, Alianza Universidad, Madrid, 1988, y muy especialmente su introducción, págs. 13-24, donde realiza una certera revisión de las interpretaciones historiográficas que esta corriente habia recibido hasta el momento.

15 Antonio Sancha-Antonio Fernández. Madrid, 1774-1776 6 vols.

is Imprenta Real, Madrid, 1789.

17 Madrid, 1785.

is Madrid, 1787-1797.

19 HeRR, Richard, España y la revolución del siglo XVII, Aguilar, Madrid, 1988, págs. 176-177.

Hispania, LV1W/, núm. 195 (1997) 213-265 
ignorar el fenómeno y decretó un aislamiento que preservaría a España de cualquier noticia sobre lo que sucedía en el país vecino y por lo tanto -debió suponer- de sus consecuencias ${ }^{20}$. Tropas en la frontera, una rígida censura de prensa, registros aduaneros de cualquier impreso francés y renovado impulso a la Inquisición eran los instrumentos dispuestos para llevar a cabo los objetivos políticos. La Ilustración fue perseguida con mayor severidad, y algunos de sus principales exponentes - Jovellanos desterrado o Campomanes destituido- sufrieron las consecuencias. Sin embargo la estrategia se vino abajo cuando en 1793 se inició la guerra contra la Convención y fue imposible eludir el contacto directo con la Francia revolucionaria ${ }^{21}$.

No se descuidó sin embargo la contrarrevolución propiamente ideológica. De un lado, se produjo una reacción religiosa que, desde posiciones ultramontanas, inició con renovado vigor la denuncia de liberales, jansenistas y propagandistas de la revolución francesa, todo ello desde la privilegiada plataforma de crítica que obtuvo el clero con la crisis económica que se iba agudizando progresivamente ${ }^{22}$. Un contingente muy importante de clérigos franceses 6.000 en 1793- llegados a España contribuyó a reforzar la convicción contrarrevolucionaria del clero español ${ }^{23}$. Se trataba de los clérigos más intransigentes con la revolución que se habían negado a aceptar la constitución civil del clero y habían sido expulsados del país ${ }^{24}$. Por otra parte, fueron apareciendo en Europa las principales obras de los autores contrarrevolucionarios "clásicos»: Emund Burke -Reflections on the Revolution in France (1790)--, Louis de Bonald --Theorie du pouvoir politique et religieux dans la société civile (1796)- - y Joseph de Maistre -Considerations sur la France (1797) - . Aunque la contrarrevolución hispana hizo uso de alguna de ellas, encontró mejor sus herramientas en autores de reconocida menor entidad ideológica como el abate francés Agustín de Barruel. En el ámbito español estaba estrictamente prohibido editar textos sobre Revolución francesa, tanto a favor como en contra ${ }^{25}$, y obras tan poco dudosas para las autoridades eclesiásticas como Causas de la Revolución de Francia en el año 1789 y medios de que se han valido para efectuarla los enemigos de la religión y del Estado, del padre Lorenzo de Hervás, no pudieron ver la luz legalmente hasta 1808.

Con motivo de la guerra contra la república, una de las más destacadas figuras del pensamiento reaccionario, Fray Diego de Cádiz, publicó El soldado cató-

\footnotetext{
20 Ibidem, págs. 200-201.

21 id. AYMES, Jean René, La guerra de España contra la revolución francesa (1793-1795), Instituto de Cultura «Juan Albert», Alicante, 1991, págs. 26-29 y 382-384.

22 LyNCH, John, El siglo xvIt, Crítica, Barcelona, 1991, págs. 360-361.

23 HeRR, Richard, España y la revolución del siglo xvil, op. cit., págs. 247-249.

24 AVELLA CHAFFER, Francisco, "El clero francés emigrado en Sevilla durante la Revolución", 1792-1800, Arch. Hispalense, 1967, ser. 2, núm. 14-146.

${ }_{25}$ En 1796 la circulación de la versión francesa de las Reflections on the Revolution in France de Burke fue prohibida en España por la Inquisición. HerR, Richard, op. cit., pág. 245. También Elorza, Antonio, «La formación del liberalismo en España», en Fernando Vallespin (ed). Historia de la teoría politica, 3, Alianza Editorial, Madrid 1991, pág. 405.
} 
lico en la guerra de religión. Carta instructiva, ascético-histórico-politica... ${ }^{26} \rightarrow$, una obra en la que se anticipaba la función que el clero iba a cumplir durante la guerra de la Independencia orientando el conflicto como una guerra de religión. En este segundo momento destacaron Rafael de Vélez y el Padre Alvarado, conocido por el Filosofo Rancio. En la obra del primero, como apologista del Antiguo Régimen y radicalmente enfrentado a la Revolución francesa, son de reseñar Preservativo contra la irreligión ${ }^{27}$ y Apología del Altar y del Trono ${ }^{28} \mathrm{y}$ la obra del destacado publicista reaccionario, el padre Alvarado, apareció en sus Cartas aristotélicas y en las Cartas críticas ${ }^{29}$.

c) Desde la publicación de la Constitución de 1812. Con la guerra de la Independencia la posición de los sectores contrarrevolucionarios alcanza toda su complejidad. La producción ideológica se había ido consolidando con el tiempo y también se había dejado sentir su influencia sobre la política, sin embargo, en medio de la crisis del Estado absoluto, el mismo que se había beneficiado de sus doctrinas, y puesto en entredicho el proyecto ilustrado bajo la acusación de afrancesamiento, aparece la Constitución del 1812 que da carta de naturaleza al proyecto liberal español. Desde este momento la contrarrevolución no puede continuar razonando en términos nacionales, señalando un enemigo que siempre había venido del exterior y era diferente. Este planteamiento revolución/reacción se tornará definitivo puesto que, desde el momento de formarse las Cortes de Cádiz, la sociedad española ya no va a identificar mecánicamente revolución con extranjero e invasor, sino que se va a escindir en su visión de la realidad política descubriendo en el bando nacional dos soluciones para hacer frente al ejército napoleónico con un proyecto de estado tras de sí. Este es un momento decisivo para la contrarrevolución porque se encuentra en la necesidad de reclamar el apoyo popular para su proyecto de reacción antiliberal. El aparato estatal que había acogido hasta el momento el compromiso de actuar en defensa de sus intereses está resquebrajado y hundido, es el momento en el que la contrarrevolución se ve en el compromiso de alcanzar un verdadero protagonismo social en demanda de apoyos.

La Guerra de la Independencia fue una encrucijada clave en el desarrollo de la contrarrevolución porque sirvió como punto de unión para dos de sus trayectorias centrales. Hasta ese momento se había desarrollado fundamentalmente en el plano ideológico, incidiendo en la vertiente publicística, y siempre amparada por el poder. La contrarrevolución suministró argumentos al Estado absoluto cada vez que las doctrinas ilustradas atravesaban una crisis de confianza a los ojos de la Corona. Desde el estallido de la Revolución francesa esta relación se estrechó y se produjo una gran identificación. La revolu-

26. Barcelona, 1794.

27 Preservativo contra la irreligión, o los planes de la filosofía contra la religión y el Estado, realizados por la Francia para subyugar la Europa, seguidos por Napoleón en la conquista de España, y dados a luz por algunos de nuestros sabios en perjuicio de nuestra patria, Cádiz, 1812.

28 Madrid, 1818. Hemos manejado le edidicón de Imprenta de Repulles, Madrid, 1825.

29 Cartas críticas que escribió El Filósofo Rancio, Peninsular, Barcelona, 1881. 
ción era un fenómeno externo que preocupaba mucho a los gobernantes y la contrarrevolución proporcionaba la justificación para hacer causa común contra el invasor -primero con ideas, después con las armas-- extranjero sobre planteamientos nacionales.

Sin embargo en España la invasión se desarrolló al mismo tiempo que se producía el desplome del Antiguo Régimen, originando una crisis del Estado y un vacío de poder que dio lugar a un proceso revolucionario que permitió establecer una nueva legalidad en ausencia de la precedente ${ }^{30}$. De este modo el proceso revolucionario español se inició en torno a dos elementos, la reunión de Cortes en Cádiz y la Constitución de 1812. Esta primera aparición del liberalismo altera el planteamiento nacionalista enarbolado por la contrarrevolución ${ }^{31}$. Desde este momento ya no contará siempre con el Estado como brazo ejecutor de sus teorías políticas. En compensación, por primera vez, la contrarrevolución se encontró proporcionando ideología también en las trincheras. El hecho de que la guerra de la Independencia tuviera una vertiente de lucha contrarrevolucionaria con las armas, significa el arranque de una tradición decimonónica en la que la reacción recurrirá al apoyo popular para alcanzar sus objetivos.

En definitiva, la guerra contra las tropas napoleónicas, y el hundimiento de la monarquía absoluta que trajo consigo, puso de manifiesto a los ideólogos contrarrevolucionarios que existía un proyecto de Estado en España que no precisaba de su producción porque estaba inspirado en unas raíces políticas distintas y aún contradictorias a las suyas. Era evidente que su influencia tradicional sobre el poder se estaba desvaneciendo con gran rapidez. Por contra, la experiencia de agitación de las clases populares en una lucha contrarrevolucionaria en defensa de la Religión y del Rey abrió una vía nueva para optar al poder: la vía insurreccional. Estos dos elementos se combinarán en los sucesivos cambios políticos hasta el estallido de la guerra civil en 1833.

Aún fue posible en 1814 retomar al modelo dieciochesco en el que la monarquía encarnaba la iniciativa reaccionaria, habiendo de señalarse que halló en Fernando VII un rey particularmente dispuesto a ello. Aceptó reinar según la propuesta hóndamente reaccionaria que le hicieron los diputados arrepentidos en Valencia a través del Manifiesto de los diputados de Fernando $V I I$, el conocido "Manifiesto de los Persas", que postulaba:

La monarquía absoluta es una obra de la razón y de la inteligencia; está subordinada a la ley divina, a la justicia y a las reglas fundamentales del Estado; fue establecida por derecho de conquista o por la sumisión voluntaria de los primeros hombres que eligieron sus Reyes. Así que el soberano absoluto no tiene facultad de usar sin razón de su autoridad; por esto ha sido necesario que el poder del

30 ELORZA, Antonio, «La formación del liberalismo en España», op. cit., pág. 407.

31 AYMES, Jean RENE, La guerra de la Independencia en España (I808-18/4), Siglo XXI, Madrid, 1990 (4. '), pág. 22. y, del mismo autor, «La 'Guerra Gran' (1793-1795) como prefiguración de la'guerra del francés' (1808-1814)» en la obra bajo su coordinación España y la Revolución fran. cesa, Critica, Barcelona, 1989, págs. 316-319. 
soberano fuese absoluto, para prescribir a los súbditos todo lo que mira el interés común; y obligar a la obediencia a los que se niegan a ella ${ }^{32}$.

Mediante esta concepción de la monarquía se consumaba una propuesta contrarrevolucionaria radical "remediar lo actuado en Cádiz" y esto había de hacerse suspendiendo «los efectos de la Constitución y los decretos dictados en Cádiz». La momentánea identificación entre monarquía absoluta y contrarrevolución provocó que ambas corrieran destinos paralelos después de la revolución de marzo de 1820 y el restablecimiento del sistema Constitucional. El poder real fue restringido y sometido a una ley básica y a una cámara de representantes. La contrarrevolución dejo de inspirar la política del Estado, de ahí que dirigiera la mirada hacia la misma base social que había movilizado durante la Guerra de la Independencia bajo el genérico llamamiento nacional. Ahora tenía que hacerlo desde presupuestos apostólicos y antiliberales y, si lo conseguía, obtendría mediante la insurrección armada la capacidad de maniobra que había perdido con su desplazamiento del entorno del poder. De este modo la ideología que rodeó la insurrección antiliberal sobre el trienio manifestó un esquematismo y simplificación, basado en elementos básicos como el maniqueismo, interclasismo, providencialismo, la contrarrevolución como cruzada o el mito de la ruptura del orden originario que tienen que comprenderse en el proceso de difusión del mensaje entre las clases populares ${ }^{33}$.

De todos modos, la experiencia fue breve y no hubo lugar para la consolidación de un discurso político contrarrevolucionario adaptado a las circunstancias. El ascenso al poder a partir de 1823 de gobiernos con una clara conciencia contrarrevolucionaria, impidió que la reacción se consolidara sobre valores insurreccionales ya que nuevamente disponía de la maquinaria estatal para imponerse. Cuando fue necesario se establecieron nuevos mecanismos voluntarios realistas, o juntas de purificación-que facilitaron la tarea. Lo que sí hizo la corriente contrarrevolucionaria que orientó la política de Fernando VII tras su segunda restauración, fue aprovechar algunas de las piezas básicas sobre las que las partidas realistas habían basado su argumentación. Destacadamente el binomio Altar y Trono, como síntesis que recogiera el hecho indiscutible de haber restituído la Monarquía a sus términos tradicionales.

\section{el desarRollo de UNA IDEOLOgí CARLISTa}

En todo este proceso que lleva de la polémica antiilustrada hasta las posiciones contrarrevolucionarias, y que comienza siendo interpretado en términos nacionalistas contra un enemigo exterior que pervierte las esencias

32 Vid. «Manifiesto de los Persas» en El Fradicionalismo español del siglo XIX, selección y prólogo de Marrero, Vicente, Publicaciones Españolas, Madrid, 1955, págs. 59-60.

33 Vid. Rúsula, Pedro, Rebeldía campesina y guerra civil en Aragón..., op. cit., cap. 3.

Hispania. LVII/1, núm. 195 (1997) 213-265 
hispanas y termina por tener que considerar a la revolución establecida en el puente de mando y con el timón del Estado en sus manos, la guerra civil carlista es el punto definitivo. Por eso, la insurrección carlista de 1833-1840 va a precisar de la sintesis del pensamiento contrarrevolucionario producido hasta el momento con distintos motivos. La duración del conflicto proporcionó las condiciones para ello.

En una primera etapa la producción ideológica fue elemental, reducida a la obtención de una finalidad eminentemente práctica y que se apoyaba sobre tópicos reaccionarios, que ya habian aparecido con anterioridad, a los que se añadían referencias a don Carlos como rey ${ }^{34}$, así se aprecia en el estudio sobre Aragón, Valencia y una parte de Cataluña. Sin embargo, el paso del tiempo y el establecimiento de una zona de control carlista en torno al Bajo AragónMaestrazgo trajo consigo una mejora en las condiciones que permitió a los cuadros dirigentes plantearse cuestiones menos perentorias de las que habian absorbido sus energías en los primeros tiempos de guerra. Desde 1836 se apreció en las fuerzas carlistas que mandaba Cabrera un proceso de institucionalización que tuvo efectos en el ámbito administrativo, en el económico y judicial e incluso en el militar. Para ser completo este proceso debería extenderse también al ámbito ideológico, ya que un foco de poder como aquel que reclamaba el trono de España para don Carlos tenía ante sí una labor pendiente: la construcción de una legitimidad. De este modo, cuando las necesidades más apremiantes remitieron algo, comenzó a publicarse el Boletín del Real Ejército del Reyno de Aragón, el órgano oficial cuyo objeto fundamental fue nutrir ideológicamente al carlismo en la zona de Levante ${ }^{35}$. Bajo su apariencia de boletín oficial, su mision era dejar constancia de que existía capacidad argumental para oponerse a la prensa liberal. Las muy escasas disposiciones oficiales que publicaba se vieron rápidamente superadas por la interpretación de noticias procedentes de otros periodicos y la presencia decisiva de artículos de fondo y otros procedentes de la propia redacción.

Desde una perspectiva global la prensa carlista en Aragón y Valencia es un ejemplo muy importante de la ideología que la élite del movimiento -la imprenta y sus dependencias estuvieron todo el tiempo en manos de eclesiás-

34 Vid. RúJUl, Pedro, Rebeldía campesina y primer carlismo..., op. cit., el capitulo V titulado "La formación de una ideología carlista".

35 Navarro Cabanes, José, Apuntes bibliográficos de la prensa carlista, Sanchis, Tarres y Sanchis, Valencia, 1917 y Asín, Francisco, "Desde el regreso de Fernando VII hasta "La Gloriosa" (1814-1868)x, en VV. AA., Historia del periodismo en Aragón, Diputaciones de Huesca, Zaragoza y Teruel y Asociación de la Prensa de Zaragoza, Zaragoza, 1990, págs. 37-42.

Son escasos los trabajos dedicados al estudio de la prensa carlista, podemos citar tres de ellos, URQUUJo, José Ramón, «Prensa carlista durante la primera guerra (1833-1840)", en La prensa en la Revolución liberal, Universidad Complutense, Madrid, 1983, págs. 319-336, MADARIAGA ORBEA, Juan José y TAmayo ERrazQuin, José Angel, Prensa oficial carlista en el contexto de la primera guerra: «Gaceta oficial» y aBoletín de Navarra y las Provincias Vascongadas». (1835-1839), texto mecanografiado, 1979, y MUNDET I GIFRE, Josep M., «El Restaurador Catalán y la primera guerra carlina, Rafael Dalmau, Barcelona, 1980. 
ticos - produjo para su propio consumo y para justificación hacia el exterior de que existía un pensamiento enjundioso que respaldaba sus posiciones y también su autoridad. El exterior es sin duda el bando liberal frente a quién trató de dar una imagen de solidez, pero también los propios soldados, la base del movimiento que no leía por sí misma la prensa sino que la escuchaba o dejaba que le fuera explicada. Los refinamientos intelectuales de la cultura escrita no fueron patrimonio de las tropas combatientes en la guerra con los carlistas, apenas llegaron a participar de versiones vulgarizadas de ella que mucho se asemejaban al pequeño repertorio de tópicos reaccionarios con el que ya estaban familiarizados. Frente a ellos, un periódico carlista que aparecía tres veces a la semana tenía un valor fundamentalmente icónico.

Sin embargo, la prensa carlista es el conjunto documental más importante a nuestra disposición para analizar la ideologfa producida por la élite insurreccional en Aragón y Valencia; todo un modo de comprender la realidad que conviene sea analizado para comprender las razones y los objetivos que animaron su acción. Para adentrarse no sólo en los argumentos desarrollados, sino también en los elementos básicos en los que se apoyan y en el modo que tienen de ser estructurados, aspectos ambos que son en este caso elementos determinantes de la lógica y la tensión internas, pueden establecerse tres niveles: el de los términos, el de los conceptos y el de las ideas.

\section{Los términos}

El objetivo carlista de elaborar un entramado ideológico que justificara sus aspiraciones tuvo que partir desde sus elementos básicos, las palabras. Términos nuevos se combinan con otros de uso anterior para articular una argumentación política que no es estrictamente tradicional sino que, debido a los importantes cambios que se habian producido, tanto en el ámbito de la revolución como en el de la reacción, se vio obligada a orientar el sentido del discurso en una nueva dirección marcada por el conflicto presente. Desde esta perspectiva los térninos de la argumentación son muy valiosos como testigo ya que reflejan la naturaleza de los materiales de los que se componen las ideas de la contrarrevolución. Por otro lado, las tendencias que se identifican en la terminología empleada, sus reiteraciones y centros temáticos en torno a los que evolucionan, indican de un modo harto evidente cuales son los objetivos centrales de la argumentación y, lo que es más importante, cual es la lógica interna de estos conceptos que opera a su vez sobre el razonamiento general cuando se hace uso de ellos.

Existen cuatro núcleos principales en torno a los que se aglutinan los términos de uso habitual en la argumentación carlista. A su vez existen relaciones internas que permiten agruparlos por parejas en función de dos ejes. El primero de ellos responde a la necesidad de defender el núcleo fundamental, Altar y Trono, de ahí que se centre en torno a la Religión, por una parte, y al Estado-revolución, por la otra. Este eje de la terminología, aunque responde a la misma dinámica, es manifiestamente distinto del otro que se constituye

Hispenia, LVI]/1, núm. 195 (1997) 213-265 
sobre el lenguaje. Tratándose de una visión del conflicto dialéctica y muy retórica, el papel del lenguaje empleado fue decisivo, tanto si se considera el practicado por los liberales, como el desarrollado por la contrarrevolución para tratar de invertir la lógica del discurso liberal.

A través de esta modalidad de análisis, tan esquemática, de la terminología quedan de manifiesto los ámbitos fundamentales sobre los que deseaba operar la ideología carlista: la defensa de los pilares del Antiguo régimen - Religión y Trono- $y$, frente a la revolución, combatiendo el racionalismo liberal a través de la desautorización del lenguaje y ofreciendo una visión sustitutiva.

\section{Religión}

La terminología que gira en torno a la Religión reitera la máxima contrarrevolucionaria "Rey y Religión" ${ }^{36}$ aunque con mucha más frecuencia los términos se invierten para expresarse en la forma "Altar y Trono" ${ }^{37}$, potenciando de este modo la primacía del factor religioso. En lo positivo, lo enunciativo, la sencillez es la norma, y las ideas simples no se desarrollan, ni se distorsionan en argumentaciones, sino que se afirman una vez tras otra en manifestación de su verdad. Sin embargo, lo que en los aspectos enunciativos es básico, escaso de recursos, sencillo, se torna exuberante, variado, cargado de matices en la expresión de lo otro, lo que es distinto, es decir manifestación de que los liberales son "enemigos de Dios, del Rey y de la Patria" ${ }^{38}$, en este orden.

Los recursos léxicos puestos a su servicio para mostrar la parte oscura son excepcionales y muy cualificados para dejar pocas dudas sobre la ignominia de la que participaban quienes no apoyaban a don Carlos. El enemigo puede ser caracterizado como un elemento extraño a la sociedad, que la perturba desde fuera con su presencia. Se habla de "vándalos» ${ }^{39} \mathrm{y}$ también reiteradamente de "ateos ${ }^{40}$, «anticristos» ${ }^{41} y$, como no, de «judíos» ${ }^{42}$ o de «israelitas» ${ }^{43}$, todo lo cual implica la defensa del patrimonio esencial a toda la sociedad católica. No en vano se dirigió una buena parte de la terminología de temá-

\footnotetext{
36 Boletín del Ejército Real de Aragón, Valencia y Murcia, núm. 65,6 de septiembre de 1837.

37 Boletín del Real Ejército de Aragón, núm. 28, 19 de febrero de 1837 y Boletín del Ejército Real de Aragón, Valencia y Murcia, núms. 52 y 53 de 19 y 22 de julio de 1837.

38 Boletín del Ejército Real de Aragón, Valencia y Murcia, 24 de noviembre de 1838.

39 Boletín del Real Ejército de Aragón, núms. 30 y 37, 1 de marzo y 23 de abril de 1837.

40 Boletín del Ejército Real de los Reynos de Aragón, Valencia y Murcia, núm. 41, 7 de junio de 1837 y Boletín del Ejército Real de Aragón, Valencia y Murcia, núms. 48 y 101 de 5 de julio de 1837 y 10 de enero de 1838 .

${ }_{41}$ Boletín del Ejército Real de los Reynos de Aragón, Valencia y Murcia, núm. 41, 7 de junio de 1837.

${ }^{42}$ Boletín del Ejército Real de los Reynos Unidos de Aragón, Valencia y Murcia, núm. 44, 21 de junio de 1837.

${ }^{43}$ Boletín del Ejército Real de Aragón, Valencia y Murcia, núm. 47, I de julio de 1837 y 7 de marzo de 1838.
} 
tica religiosa hacia la "corrupción de costumbres" ${ }^{44}$ que habían introducido los liberales, conceptos que andan muy unidos como en la expresion "hombres desmoralizados, sin religion y sin costumbres" ${ }^{45}$. Y desde esta plataforma de hombres que han atentado contra las costumbres, la tradicion española, se orientan ataques hacia diversas direcciones. Por una parte se señala el ataque a la moral que supone esta iniciativa caracterizada por el «libertinaje» "46, protagonizada por un auténtico "ejército de materialistas" ${ }^{47}$ o "banda revolucionaria" ${ }^{48}$. También se maneja un léxico amplio para indicar la conspiración contra la religión protagonizada por estos «sectarios de la impiedad" "49 auténticos «hijos de las tinieblas" ${ }^{50} \mathrm{y}$ "enemigos de la religión" ${ }^{51}$ que no es sino la consecuencia final de la «impiedad revolucionaria» que les animaba. Por último existe una vertiente que atribuye un carácter contrarreligioso al liberalismo, sin demasiados problemas para presentarlo como una "facción sacrílega, sedienta de sangre" ${ }^{52}$ que desde que había llegado al poder tenía «destinados los altares a pesebres" ${ }^{53}$ y había entregado el país a «un gobierno que ha anatemizado la Religion Divinan ${ }^{54}$.

\section{Estado}

Sobre la terminología empleada para tratar los asuntos referentes al poder político puede suscribirse lo dicho para la religión donde, frente a un esquematismo elemental de los vocablos positivos, existen una variedad infinita de formas para nombrar al enemigo. Esto tiene importantes implicaciones de orden lógico ya que supone, de antemano, que la posición carlista está defendiendo lo permanente, lo esencial, lo que no es necesario nombrar porque de ello se participa plenamente mientras que el agresor, el enemigo ajeno, el "extranjero" ${ }^{55} \mathrm{o}$ el abárbaro" ${ }^{56}$ tiene que ser nombrado para que exista, capturado en las palabras, mostrado en su diferencia, para ser entregado a la sociedad que deberá destruirlo por ser una amenaza contra lo fundamental.

\footnotetext{
44 Boletín del Real Ejército del Reyno de Aragón núm. 17, 6 de septiembre de 1836.

45 Boletín del Ejército Real de Aragón, Valencia y Murcia, núm. 141, 2 de junio de 1838.

46 Boletín del Ejército Real de Aragón, Valencia y Murcia, núm. 49, 8 de julio de 1837 y Boletín de Aragón, Valencia y Murcia, núm. 23, 13 de junio de 1839.

47 Boletín del Ejército Real de Aragón, Valencia y Murcia, núm. 62, 25 de agosto de 1837.

48 bidem.

49 bídem, núm. 48 y [50], 5 y 12 de julio de 1837.

so tbídem, núm. 52,19 de julio de 1837 .

s1 Ibidem, núm. 62, 25 de agosto de 1837.

\$2 Ibídem, núm. 69, 18 de septiembre de 1837.

53 lbídem, 7 de febrero de 1838.

54 Ibídem, 24 de febrero de 1838.

55 Ibídem. núm. 65, 9 de septiembre de 1837.

56 Boletín del Ejército Real de los Reynos Unidos de Aragón, Valencia y Muria, núm. 46, 28 de junio de 1837.

Hispania, LVII/1, núm. 195 (1997) 213-265
} 
Asi, el primer bloque de contenido que designa la terminologia es la existencia de una filosofía ilustrada con atributos, siempre negativos, que inspira la revolución. Esa "Ilustración" ${ }^{57}$, esa "filosofia" ${ }^{58}$ está personalizada en unos "filosofos" ${ }^{59}$ que no son sino "pseudo filósofos" ${ }^{60} \mathrm{o}$ "farsantes ilustrados" ${ }^{61}$ cuya argumentación se establece sobre "sofismas" ${ }^{62}$ y su modo de comportamiento social les atrae el nombre de "libertinos" ${ }^{63}$, es decir, practicantes del «libertinaje» ${ }^{64}$.

Otro eje director es el revolucionario donde abundan las referencias a la Revolución francesa como paradigma del horror revolucionario. Ese es el referente cuando se emplean los términos "patriota" 65 o "terrorismo" ${ }^{66}, \mathrm{y}$ siempre que se hace referencia a los arepublicanos" ${ }^{67}$, apareciendo imbricados en ocasiones con referencias a Robespierre ${ }^{68}$. Con el punto de comparación establecido, la crítica de lo que sucede en España adquiere una riqueza de matices. No hay ninguna duda de que se trata de una "revolución» ${ }^{69}$, una "revolución española" ${ }^{70}$ que tiene como proyecto establecer un «sistema revolucionario" " Entre los apoyos con los que cuenta están los "generales revolucionarios" ${ }^{72}$. Y los perfiles finales de este proyecto se vislumbrar como un atentado contra la religión, "revolución atea" ${ }^{73}$, "revolución impía" ${ }^{74}$, contra la religión y el orden, "revolución anárquica e impía " 75 o contra el trono legítimo "revolución usurpadora" ${ }^{76}$. Todo un catálogo de donde veía la reacción que operaban las fuerzas revolucionarias. Consideraban además que el liberal era un "partido infame y desor-

\footnotetext{
57 bídem, núm. 46, 18 de septiembre de 1837.

s8 lbídem, núm. 46 y Boletín del Ejército Real de Aragón, Valencia y Murcia, núms. 46, 65, 74 y 74 bis.

59 Boletín del Ejército Real de los Reynos de Aragón, Valencia y Murcia, núm. 41, 10 de junio de 1837 .

6it Boletín de Aragón, Valencia y Murcia, núm. 44, 6 de agosto đe 1839.

6) Boletín del Ejército Real de Aragón, Valencia y Murcia, núm. 47, 1 de julio de 1837.

Ћ2 Boletín de Aragón. Valencia y Murcia, núm. 43, 1 de agosto de 1839.

${ }^{63}$ Boletín del Ejército Real de los Reynos de Aragón, Valencia y Murcia, núm. 41 y Boletín del Ejército Real de Aragón, Valencia y Murcia, núm. 62, 25 de agosto de 1837.

(tA Boletín del Ejército Real de Aragón, Valencia y Murcia, núm. 101, 10 de enero de 1838.

65 lbídem, núm. [50], 12 de julio de 1837.

t6 Ibídem, núm. 60, 17 de agosto de 1837.

67 Boletín del Ejército de los Reynos de Aragón, Valencia y Murcia, núm. 41, 7 de junio de 1837 y Boletín del Ejércio Real de Aragón, Valencia y Murcia, núms. 48 y [50], 5 y 12 de julio de 1837.

68 Ibídem, núm. [50] 12 de julio de 1837.

69 lbídem, núm. 48, 5 de julio de 1837.

70 lbídem, núm. 49,8 de julio de 1837 .

71 Ibídem, núm. [50], 12 de julio de 1837.

72 Jbidem, núms. 69, 18 de septiembre de 1837 y 31 de enero de 1838.

73 lbidem, 17 de febrero y 7 de marzo de 1838 .

74 Ibidem, núm. 52, 19 de julio de 1837.

75 Ibídem, núm. 69, 18 de septiembre de 1837.

76 lbídem, núms. 58 y 65, 12 de agosto y 6 de septiembre de 1837 .
} 
ganizador» ${ }^{77}$ que tenía como proyecto la "anarquía» ${ }^{78}$ de ahí que no dudara en hablarse del «delirio liberal» 79.

En este nivel básico, el de la terminología empleada en la argumentación contrarrevolucionaria, ya se perfila la concepción conspirativa del avance liberal. No faltan las referencias a los "clubs» ${ }^{80}$ y a las «logias" 81 que reúnen a los "negros" ${ }^{82}$, "negros atletas" ${ }^{83}$ revolucionarios de un «negro partido" ${ }^{44}$. Son reiteradas las apariciones de "sectas» ${ }^{85}$ entre los escritos, integradas igual por "masones" ${ }^{86}$ que por "comuneros» ${ }^{87}$. También se detecta una tendencia a censurar el cambio de talante que introduce el liberalismo en relación a los negocios y a la racionalidad económica de la acción pública y privada. Señalan su "ambición" ${ }^{88}$ y su interés por el "oro" ${ }^{89}$ y esto lleva en un crescendo a calificarlos de "egoístas" ${ }^{90}$, "peseteros" ${ }^{91}$ y "venales" ${ }^{92}$. Son sin duda los chirridos que despide la maquinaria del Antiguo Régimen cuando aprecia que la economía comienza a llevar el ritmo que impone el capitalismo.

\section{El lenguaje liberal}

Los dos últimos ejes en torno a los que gira la terminología contrarrevolucionaria están relacionados con la función del lenguaje como horma para la expresión del pensamiento político. De una parte el liberalismo introduce

\footnotetext{
77 Ibidem, núm. 68, 16 de septiembre de 1837.

78 Boletín del Ejército Real de Aragón, Valencia y Murcia, núms. 48, 65 y 69, 5 de julio, 16 y 18 de septiembre de 1837 y núms. 16 y Boletín de Aragón, Valencia y Murcia, núms. 47, 25 de mayo y 10 de agosto de 1839

79 Boletín del Ejército Real de Aragón, Valencia y Murcia, núm. [50], 12 de julio de 1837.

80 Boletín del Real Ejército del Reyno de Aragón, núm. 22, 21 de diciembre de 1836.

81 lbídem.

82 Boletín del Real Ejército del Reyno de Aragón, núm. 22, 21 de diciembre de 1836, Boletín del Real Ejército de Aragón, núms. 28 y 36, 19 de febrero y [] de abril de 1837 y Boletín del Ejército Real de los Reynos de Aragón, Valencia y Murcia, núm. 41, 7 de junio de 1837.

${ }^{83}$ Boletín del Ejército Real de Aragón, Valencia y Murcia, núm. 76, 11 de actubre de 1837.

84 Ibídem, núm. [50], 12 de julio de 1837.

8 Ibídem, núms. 65 y 101, 6 de septiembre de 1837 y 10 de enero y 3 de febrero de 1838 .

86 Boletín del Ejército Real de los Reynos de Aragón, Valencia y Murcia, núm. 41, 7 de junio de 1837 y Boletín del Ejército Real de Aragón, Valencia y Murcia, núms. 83 y 92, 4 de noviembre y 9 de diciembre de 1837.

Boletín del Ejército Real de los Reynos de Aragón, Valencia y Murcia, núm. 41, 7 de junio de 1837.

88 Boletín del Real Ejército de Aragón, núm. 30, 8 de marzo de 1837.

89 lbídem, núm. [30], 8 de marzo de 1837.

90 Boletín del Ejército Real de los Reynos Unidos de Aragón, Valencia y Muncia, núm. 44, 21 de junio de 1837.

91 Boletín de Aragón, Valencia y Murcia, núm. 6, 2 de mayo de 1839.

92 Boletín del Ejército Real de los Reynos de Aragón, Valencia y Murcia, núm, 41, 7 de junio de 1837.
}

Hispania, LVII/I, núm. 195 (1997) 213-265 
un mensaje político apoyado sobre un lenguaje que se distingue del empleado por los teoricos del absolutismo en la forma. El lenguaje liberal es distinto del carlista en la apariencia, de modo que, sin entrar en el contenido, el discurso liberal ya estaba manifestando, implícitamente, que proponía algo nuevo. Pero no hay que creer que el lenguaje fue un arma exclusiva del liberalismo. La contrarrevolución también lo puso a su servicio en la inversión de la lógica del discurso liberal de modo que presuponiendo algunos elementos centrales del discurso, se persuadiera al lector de que los usurpadores, los insurrectos, eran los otros, los enemigos.

Desde el punto de vista contrarrevolucionario los liberales habfan hecho uso del lenguaje como instrumento de "seducción" ${ }^{93}$ de las gentes que llegan a los brazos de su proyecto político, no por conocimiento sino por los efectos de una forma exuberante. Pero en el fondo ese «lenguaje» ${ }^{94}$ que han instrumentalizado los liberales no es sino un «lenguaje campanudo" ${ }^{95}$ y un «lenguaje hipócrita» ${ }^{96}$. Como inspirados por la falsa filosoffa "ilustrada" los artífices de este lenguaje son "pseudo filósofos" ${ }^{97}$, "cobardes" ${ }^{98}$ por emplear la palabra como arma, "demagogos" ${ }^{99}$ porque su argumentación es considerada sofística y, también, por creerla artificiosa, vacía de mensaje, «pedante» 100.

Por lo tanto, ese ejercicio de seducción que es el lenguaje liberal es la clave del efecto que la revolución está teniendo en España, el efecto del «narcótico revolucionario» ${ }^{101}$ que está obstruyendo las mentes de lo auténtico para conducirlas inermes hacia los peligros del "liberalismo revolucionario" ${ }^{102}$. El resto es simple "espíritu de proselitismo" ${ }^{103}$ como medio para alcanzar sus propósitos «egoístas».

\section{La inversión de la lógica del discurso liberal}

A pesar de las acusaciones vertidas contra el liberalismo, la contrarrevolución hizo cuanto pudo por utilizar el lenguaje como instrumento a su servi-

93 Boletín del Real Ejército de Aragón, núm. 30, 8 de marzo de 1837.

94 Boletín del Ejército Real de Aragón, Valencia y Murcia, 2 de junio de 1837.

95 lbídem, núm. [50], 12 de julio de 1837.

96 Ibídem, núm. 55,29 de julio de 1837 .

97 Boletín del Ejército Real de los Reynos de Aragón, Valencia y Murcia, núm. 44, 21 de junio de 1837.

98 Boletín del Real Ejército de Aragón, núm. 36, [ ] abril de 1837.

99 Boletín del Ejército Real de los Reynos Unidos de Aragón, Valencia y Muria, núm. 43, 17 de junio de 1837 y Boletín del Ejército Real de Aragón. Valencia y Murcia, núms. 55 y 68, 29 de julio y 16 de septiembre de 1837 .

${ }_{100}$ Boletín del Ejército Real de los Reynos Unidos de Aragón, Valentcia y Murcia, núm. 44, 21 de junio de 1837 .

101 Boletín del Ejército Real de Aragón, Valencia y Murcia, núm. 56, 2 de agosto de 1837.

${ }_{102}$ Ibidem, núm. 82, 1 de noviembre de 1837.

103 Ibidem, núm. 100, 6 de enero de 1838. 
cio. Se produjeron ejercicios de intención simple como el uso de citas en latín en busca de la imagen del saber antiguo como base de su verdad, o el recurso frecuente a las autoridades, sin embargo no fueron estrategias globalizadoras. La más importante, por sus implicaciones generales a partir de la utilización de una terminología determinada, fue la inversión de la lógica del discurso propuesta por el poder detentado por los liberales.

El planteamiento es elemental, pero sus efectos - como pudo comprobarse más recientemente durante el franquismo- evidentes. Consiste en invertir los términos en un proceso insurreccional, de modo que se confundan poder y rebelde a éste, hasta el extremo de asentar sobre esta confusión un argumento contrario a la realidad y, como veremos más adelante, a la historia. La clave es el binomio usurpación/lealtad . La Corona de España ha sido apropiada ilegalmente por "la usurpación" 104 en favor de una "huérfana" ${ }^{105}$ a quien no le corresponde y administrada por un «ilegal gobierno" ${ }^{106}$ que hablando tanto de libertad ha sometido a los españoles a la "esclavitud más ignominiosa» ${ }^{107}$. Frente a ellos se encuentran las filas de "la lealtad» ${ }^{108}$ el verdadero rey de España, Carlos V. De su parte se encuentra la legalidad y enfrente los «rebeldes» 109 mandados por unos jefes que no reciben el nombre de oficiales sino de "cabecillas" 110 . Lo sucedido ha sido únicamente producto de la acción de unos "pérfidos y desleales vasallos" " que se han rebelado contra la legalidad del rey legitimo reduciendo España a un "país ocupado por los enemigos» 112. Desde esta perspectiva, la regencia de María Cristina y sus gobiernos son quienes han protagonizado una insurrección contra el trono legítimo de Carlos V, quienes han llevado a cabo un acto de usurpación.

\section{Los conceptos}

La expresión de la ideología del absolutismo no se apoyaba de forma importante sobre conceptos. Sabedores sus artífices que se hallaban en disposición de la única verdad y respaldados por el poder, sólo precisaron de una recreación más genérica de ese único modo de pensar cierto. Sin embargo, una de las consećuencias de la aparición del racionalismo liberal en el ámbito

104 Boletín del Real Ejército de Aragón, núm. [30], 8 de marzo de 1837, Boletín del Ejército Real de los Reynos de Aragón, Valencia y Murcia, núm. 41, 7 de junio de 1837 y Boletín del Ejército Real de Aragón, Valencia y Murcia, núms. 48, 49, 46, 58, 62, 67 y 86, 5 y 8 de julio, 2, 12, y 25 de agosto, 6 y 13 de septiembre y 12 de noviembre de 1837 .

105 Boletín del Ejército Real de Aragón, Valencia y Murcia, núm. [50], 12 de julio de 1837.

106 Boletín Aragón, Valencia y Murcia, núm. 54, 29 de agosto de 1839.

107 Boletín del Ejército Real de Aragón, Valencia y Murcia, núm. 56, 2 de agosto de 1837.

108 Ibidem, núm. 52, 19 de julio de 1837.

109 lbidem, núm. 81, 28 de octubre de 1837.

110 Boletín del Real Ejército de Aragón, núm. 30, 1 de marzo de 1837.

III Boletín del Ejército Real de Aragón, Valencia y Murcia, núm. 101, 10 de enero de 1838.

112 Jbídem, núm. 36, 13 de julio de 1839. 
político fue la entrada en escena de algunos conceptos básicos que debía difundir como principios de su ideario. En esta circunstancia, y dada la esencia dialéctica de la contrarrevolución, la reacción se vio forzada a bajar a la arena de los conceptos, no con formulaciones propias sino con las mismas que el liberalismo se había propuesto difundir. Por ello es valioso comprobar ese otro nivel en la configuración de la ideología carlista que son los conceptos que utiliza y en los que ya se perfila el profundo espíritu reaccionario que anima su pensamiento. Conceptos operativos que articulan la respuesta contrarrevolucionaria frente a los avances liberales. Algunos de los más significativos son: filosofía, revolución y libertad.

\section{Filosofia}

El concepto filosofia contiene en el discurso contrarrevolucionario la esencia la Ilustración. A ella se atribuyen la introducción de cambios en la sociedad, la corrupción de las costumbres como fase necesaria en la desintegración de la sociedad española previa al desembarco de la revolución, dentro todo del marco de una conspiración: «...por eso tomaron tanto empeño en entibiar el fervor español para su Religión; en hacernos cambiar de ideas, y singularmente en corromper nuestras costumbres; a este fin nos introdujeron tanto a multitud de libros extranjeros, ya traducidos en nuestro idioma, ya en su misma lengua nativa que cambiaron en gran parte la opinión pública. Antes que reventase el volcán de la revolución francesa, habían ya conseguido fascinar a algunos de nuestros españoles preciados de sabios y de despreocupadosw 113 .

La conspiración filosófica se caracterizaba por el objetivo de introducir la revolución en España en un proceso que se había iniciado en la segunda mitad del siglo xvir y seguía los pasos a los sucesos de Francia.

...d'Alambert se gloriaba en su carta de 3 de mayo de 1773 que la nueva filosofía, es decir, la impiedad más descarada, y la mayor enemiga de toda Religión y autoridad legítima había por fin penetrado sordamente en España al lado de la Inquisición, pero estos triunfos eran de poca consideración, y no ofrecían a la secta liberal más que unas pequeñas ventajas. La revolución francesa y la paz ignominiosa que hizo con sus autores, un ministro español tan ignorante como inmoral llenaron de esperanzas a los filósofos revolucionarios, que desde luego formaron el proyecto de conquistar la España ${ }^{114}$.

El objeto central de esta trama lo constituía la Religión por lo que el jansenismo que «se introdujo en España como por un encantamiento mágico», era parte importante de aquella conspiración. "Casi todos los jansenistas, como era regular, prestaron sus brazos a los filósofos revolucionarios». El

113 Ibídem, 3 de febrero de 1838.

il 1 lbidem, 3 de febrero de 1838. 
proceso de asalto continuó con la guerra de la independencia. «España se vio atacada por numerosas bandas del jefe de los filósofos Napoleón Bonaparte». Y los efectos de la filosofía operaron a modo de narcótico lento al que se opusieron algunas resistencias en momentos determinados. «Creció rápidamente esa planta mortífera y los males que nos amenazaban horrorizaron a la mayoría de la nación; pero no la instruyeron bastante; el decreto del Rey Fernando de 4 de mayo del año 1814 cortó el árbol y sofocó el fuego, mas quedaron las raíces" 115. La perspectiva histórica de los efectos de la filosofía es clave y, al mismo tiempo, son identificados los apoyos por donde se extienden sus sectarios para tomar el poder. El papel de los emigrados es importante en este planteamiento. Regresaron del exilio "algunos iniciados en los principios de la secta y no pocos volvieron franc-masones declarados». Pero afectó también a todos los ordenes de la sociedad española.

La seducción no se limitó en el círculo del ejército, se extendió también a las demás clases, se alucinó al comercio ofreciéndole, que verificada la revolución, serian menos las trabas en sus especulaciones mercantiles; hasta al bajo pueblo se le procuró alucinar llenando su fantasía con el sueño de una soberanía quimérica, la que solo querían para sí mismos los agentes de la revolución: la libertad y la igualdad eran dos sirenas encantadoras y por desgracia tenía España pocos Ulises ${ }^{116}$.

De ahí que la filosofía sea un concepto central para explicar los acontecimientos desde la perspectiva contrarrevolucionaria, y citado con mucha frecuencia 117 como la pieza clave para comprender la desintegración conspirativa de la Religión y del Estado a partir de la Ilustración.

\section{Revolución}

La misma argumentación justifica la necesidad de un concepto muy definido de revolución porque es otro de los apoyos centrales para construir su visión contrarrevolucionaria. La revolución y sus principales agentes operan a través de la corrupción de costumbres. «La influencia de los principios revolucionarios que de tantos males inunda a España y al mundo entero, ha generalizado desde los últimos años del siglo anterior, elevada la impiedad a la mayor impudencia, expresiones obscenas, blasfemas e irreligiosas, expresiones que la educación bastaría a proscribir en época menos corrompida" "11. La revolución española se presentaba con el atributo de ser republicana, en

\footnotetext{
115 Boletín del Ejército Real de Aragón, Valencia y Murcia, 10 de febrero de 1838.

II6 Boletín del Ejército Real de Aragón, Valencia y Murcia, 12 de diciembre de 1838.

117 Vid, a modo de ejemplo, Boletín del Ejército Real de los Reynos Unidos Aragón, Valencia y Murcia, nưm. 46 y Boletín del Ejército Real de Aragón, Valencia y Murcia, núms. 46, 65, 74 y 74 bis.

118 Real orden dada en Villafranca, 17 de julio de 1836, Boletín del Real Ejéncito del Reyno de Aragón, núm. 17, 15 de octubre de 1836.

Hispsania, LVI]/1, núm. 195 (1997) 213-265
} 
un inequívoco paralelismo con la francesa $y$, por lo tanto, se identificaban siempre sus tendencia hacia la eliminación de la monarquía. Así, era señalado como "entre los diferentes partidos que dividen a nuestros liberales revolucionarios, y que se disputan encarnizadamente la primacía, ni uno solo existe que haya pensado jamás en edificar para Madama Isabel un Trono, que lo sea en realidad: todos se han convenido en derrocar, no ya las proporciones de la escalinata, sino al Trono mismo" "I9. Otra de las características definitorias de la revolución es la impiedad ${ }^{120}$. En ocasiones se contrapone abiertamente religión y revolución destacando los indudables efectos contrarrevolucionarios del cristianismo sobre la sociedad ${ }^{121}$. Todo ello configura un concepto de revolución sesgado hacia la vertiente de revolución ideológica que supone como heredera intelectual de las luces, pero de escaso calado social ya que no atiende a su proyecto político sino como desestabilizador del anterior sostenido con el apoyo de la Religión.

\section{Libertad}

Uno de los conceptos que más combatió el carlismo fue el de libertad, esa libertad, "tan cacareada" ${ }^{122}$, que sirvió de carta de presentación al liberalismo ante la sociedad y frente al absolutismo. Dos estrategias distintas se aprecian frente al concepto libertad. La más inteligente consiste en despojar el concepto de las implicaciones que habían incorporado la Ilustración y la Revolución francesa y apropiárselo posteriormente. Negando sus matices de independencia, razón, insumisión o rechazo del orden social estamental, el concepto era inocuo y podía ser asumido por la contrarrevolución, mostrando así que no era sólo patrimonio del liberalismo hablar de libertad:

¿Por qué pues la libertad ha de ser entre nuestros negros doctores independencia, y no potencia para obrar o dejar de obrar, obrar bien o mal? Porque la palabrita hipócrita que les viene como una albarda a un asno, se ha de reservar para todo aquel que se atreva a expresarse con el lenguaje de la razón. Porque, habiéndose decretado en los clubs que el mundo sea sólo dominado por cuatro pillos pedantes con nombre de padres de la patria, salidos de las tenebrosas cavernas de las logias, es necesario desordenar todo lo ordenado, rebelar contra sus superiores al que vive feliz con la sumisión que la razón y religión le dictan,

119 Boletín del Ejército Real de Aragón, Valencia y Murcia, núm. 74, 7 de octubre de 1837.

120 "Males incalculables que la impiedad revolucionaria ha causado a la Espanta», Boletín del Ejército Real de Aragón, Valencia y Murcia, núm. 100, 6 de enero de 1838 y «Tortuosidades, vue\}tas y rodeos, por cuyo medio la venenosa sierpe de la impiedad revolucionaria ha logrado desliarse en el suelo español, antes el más puro», Boletín del Ejército Real de Aragón, Valencia y Murcia, 31 de enero de 1838.

121 «Continúa del artículo anterior», Boletín del Ejército Real de Aragón, Valencia y Murcia, 11 de abril de 1838 ..

122 Boletín del Ejército Real de Aragón, Valencia y Murcia, núm, 48, 5 de julio de 1837.

Hispania, LVII/I, núm. 195 (1997) 213-265 
destruir todo lo edificado, aniquilar hasta la palabra bondad, en una palabra convertir al hombre menos aún que en bestia salvaje ${ }^{123}$.

Sin embargo, ésta no fue la interpretación más extendida, sino otra consistente en negar la libertad misma y atribuirle toda una serie de valores negativos que la hacían indeseable. Se niega la libertad como guía de acción política:

\begin{abstract}
...por libertad sólo habéis tenido espías que acechen vuestra respiración, fiscales que interpreten del modo más siniestro vuestras palabras hasta las más inocentes, y autoridades terroristas para encarcelar, desertar y fusilar al hombre honrado, mientras por el contrario los adalides o Corifeos constitucionales están autorizados con facultad exclusiva para robar y asesinar, faltando bien poco para que hagan públicamente lo que ciertos irracionales no se atreven como por pudor, o de vergutenza, y si posible les fuera (como lo han intentado) hasta romperfan la cadena de dependencia que hay desde el cielo a la tierra y todos los vínculos, y leyes que forman y sostienen la sociedad para tener una libertad natural que les está negada a las fieras ${ }^{124}$.
\end{abstract}

Le atribuyen características negativas, considerándola instrumento de medro personal, «libertad sólo para ellos» ${ }^{125}$ proclamaban. También se rechazaba como legítima aspiración de los pueblos. «El establecimiento de las bases de las libertades patrias, es menester mirarlo con desprecio, porque lo contrario fuera tiempo perdido; pues ya se sabe que cuanto más disparatadas sean dichas bases, tanto más satisfecha quedará la sociedad actual" ${ }^{126}$. Todo ello en una concepción de la libertad como un agente perjudicial ${ }^{127}$ que no es sino el camino hacia la esclavitud. El Objetivo de la revolución era "entronizar la falsamente dicha libertad, pero que en los efectos ha de ser la más intolerable esclavitud" 128 .

Puede continuarse el procedimiento sobre conceptos como «justician o "gobierno popular", pero el ejercicio no aportaría nuevas perspectivas. La contrarrevolución no articulo su argumentación sobre conceptos. Los conceptos fueron poco importantes, apenas existen, y cuando aparecen no son elementos propios para la articulación de las ideas sino contra-conceptos. Surgen para desmentir el valor que la revolución deposita en muchos de ellos -principios, derechos, valores,...--, desmiente y contraría su naturaleza pero pocas veces evoluciona para crear otros nuevos. El liberalismo tuvo que crear conceptos para construir en las mentes de los ciudadanos una nueva forma de comprender la realidad. La contrarrevolución solo tenía que pugnar para que

123 Boletín del Real Ejército del Reyno de Aragón, núm. 22, 21 de diciembre de 1836.

124 Firmado por LloRENs, Ramón, Boletín del Ejército Real de los Reynos de Aragón, Valencia y Murcia, núm. 41, 10 de junio de 1837.

${ }_{125}$ Boletín del Real Ejército de Aragón, núm. 30, 8 de marzo de 1837.

126 Boletín del Ejército Real de Aragón, Valencia y Murcia, núm. 40, 12 de julio de 1837.

127 Boletín de Aragón, Valencia y Murcia, núm. 39, 20 de julio de 1839.

128 Boletín de Aragón, Valencia y Murcia, núm. 49, 17 de agosto de 1839.

Hispania, LV]U/, aúm. 195 (1997) 213-265 
esto nunca se produjera, operando sobre materiales del pensamiento ya asentados en la cultura política del Antiguo Régimen. Por eso su modo de operar no fue conceptual sino nominal, apoyada en los términos, porque se refería a lo ya existente y para referirse a ello bastaba con nombrarlo, no era necesario construirlo de nuevo. Con los términos elaboró los nuevos instrumentos, las ideas indispensables para rebelarse contra la situación revolucionaria. Los conceptos no son necesarios y cuando se emplean, aplicando lo esencial de la contrarrevolución, son contra-conceptos, es decir reacciones contra los conceptos de los que se valía el liberalismo para difundir su mensaje político.

\section{Las ideas}

Siendo tan frágil el desarrollo conceptual en el que se apoyó la ideología carlista, el peso de su argumentación recayó sobre las ideas, entendiendo éstas como la formulación compleja de planteamientos procedentes de ámbitos diversos con objeto de obtener una argumentación que respaldara su acción política, y también la militar. Desde esta perspectiva, los materiales básicos que van a concurrir en la formación de las ideas serán fundamentalmente los términos y los conceptos ya analizados. Como las ideas no siempre son nitidas sino que se entremezclan circularmente configurando un entramado que cubre toda un área de contenido será útil, para aproximarse a ellas, identificar cinco ámbitos que son: Religión/Iglesia, Monarquía, liberalismo, la construcción de mitos personales y la reelaboración histórica.

\section{Léase Iglesia donde dice Religión}

Uno de los elementos principales que articuló el pensamiento carlista fue la escisión dual de la realidad en dos mitades: el bien y el mal. Esta no es una cuestión que estuviera sometida a opinión, la Iglesia se encontraba en la primera mitad y lo ajeno, lo hostil, en la segunda. Esto derivó hacia un enjuiciamiento ${ }^{129}$ permanente de la realidad desde una postura estática instalada en la verdad, no una verdad razonada y defendida frente a otras, sino la verdad, absoluta y única de la que se sabfan partícipes.

En el conflicto carlista - también dual- un planteamiento así evolucionó irremisiblemente hacia la existencia de una buena causa y una causa aviesa, defensora de lo bueno la primera y embajadora del mal esta última. "La causa justa y santa que defiende la mayoría de la Nación oprimida por la fuerza brutal, triunfará sin duda, y tal vez esté cercano el día en que el pendón legítimo tremole sobre los regios Alcázares de Madrid». Este modo de razonar llevaba directamente, sin apenas transicion, hacia el providencialismo. Si la carlista es la causa de la religión ¿cómo no iba a estar Dios de su parte?

\footnotetext{
129 Boletín del Real Ejército del Reyno de Aragón, núm. 22, 21 de diciembre de 1836.
} 
¿Y podrías Señor abandonar a los impíos el Pueblo, que aś te adora? ¿Y podrías haberles concedido un triunfo tan funesto a tu Causa y nuestra Causa, que es una misma? Sí Dios grande, Dios del poder, Dios de la misericordia, tus enemigos y nuestros enemigos son unos mismos. Esos pérfidos, que profanan y dilapidan tus Templos, son los mismos, que intentan destrozar nuestra gloriosa Monarquía: esos inicuos, que blasfeman y se lanzan contra ti y contra tu Madre Santísima, son los mismos, que osan inmolar nuestras Madres, y especular con nuestros despojos: esos monstruos, que se envanecen hacinando sobre sí anatemas y sacrilegios, son los mismos, que inundan en sangre nuestras campinaas y nuestros hogares 130 .

Dios, por lo tanto, está del lado del pretendiente don Carlos, su causa es la buena causa, así que no era de extrañar que uno de los objetivos principales de la revolución fuera acabar con la Religión. Para dar a conocer el traslado del seminario de Tortosa a Morella se argumentaba en este sentido refiriéndose a la "revolución anárquica e impía, que se ha propuesto nada menos que acabar con todo lo bueno, para promover cuanto los espiritus infernales han podido escogitar de más malignante y nocivo al género humano. Los rabiosos partidarios de la revolución atea no podían dejar de manifestarse enemigos mortales del Colegio Seminario Imperial de Tortosa" 131. Y se gloriaba el autor de que los colegiales no habían "gustado en mi ausencia el cáliz envenenado de la filosofía del siglo, cuyo ponzoñoso tóxico tan desde sus principios sus dóciles corazones tenazmente aprendieron a detestar».

Pero no dejaron de lado la vertiente pragmática de esta idea pues donde más fuerte percibieron ese ánimo de acabar de raíz con la religión fue en la abolición de los diezmos. Sobre este tema se extendió la prensa carlista largamente aportando su propia interpretación del problema ${ }^{132}$, proporcionando argumentos jurídicos ${ }^{133}$, e incluso cuestionando con argumentos liberales e introduciendo dudas - «Y quién cree que sin diezmos serán pagados los sacerdotes? Nadie» ${ }^{34}$ _, teorizando en favor del diezmo con enfoque tendencioso - «Aunque los diezmos fuesen en España una regalía, y pudiesen las cortes disponer de ellos a su arbitrio, su abolición sería impolítica, por lo que perjudicaría al Estado y al clero, sin resultar de ella ventaja alguna a la agricultura ${ }^{135}$ - y denunciando los impagos en zonas en las que habían decretado

\footnotetext{
130 "Solemnisima procesión del Corpus en Morella», Boletín de Aragón, Valencia y Murcia, núm. 24,15 de junio de 1839 .

131 "Traslación del Inperial colegio Seminario de Santiago y San Matías de Tortosa a la Real Plaza de Morella, y apertura de sus Aulas», Boletín del Ejército Real de Aragón, Valencia y Murcia, 12 de diciembre de 1838 .

132 "Comunicado", Boletín del Ejército Real de Aragón, Valencia y Murcia, núm. 49, 8 de julio de 1837.

133 "La abolición de los diezmos hecha por solo el poder temporal es nula y sacrilega", Boleín del Ejêrcito Real de Aragón, Valencia y Murcia, núm. 51, 15 de julio de 1837.

134 Boletín del Ejército Real de los Reynos Unidos Aragón, Valencia y Murcia, núm. 46, 28 de junio de 1837 .

135 Boletín del Ejército Real de Aragón, Valencia y Murcia, núm. 57, 5 de agosto de 1837.
}

Hispania, LVI111, nưm. 195 (1997) 213-265 
su exacción ${ }^{136}$. En definitiva, la abolición de los diezmos era un acto mayúsculo de impiedad liberal y una medida contra la que había que resistir con todas las fuerzas, pues estaba dirigida a aniquilar la religión en España:

Ya os entiendo, hijos de las tinieblas. Los ayunos no los conocéis, comeis carne en los días de abstinencia, y con la abolición de los diezmos añadida nuevamente a las multas pecuniarias, a los robos, tan frecuentes, a las cárceles, a los destierros y asesinatos con que hace tiempo perseguis tan cruelmente al clero español, si el Dios de las venganzas no acaba pronto con vosotros, y con vuestros inicuos planes, desaparecerá de entre nosotros esta corporación respetable que tanto os incomoda: y entonces, a Dios Mandamientos de la Iglesia; ya no tendreis Misas ni confesiones ni comuniones. Parece que Dios ha esparcido en vuestros consejos un espíritu de vértigo. En las revoluciones pasadas sus agentes jamás atacaban de frente a la Religión de nuestros mayores: eran soldados bisoños, tímidos, y cobardes, que buscaban siempre rodeos para poner en planta sus sacrílegos proyectos: vosotros os hallais más adelantados en el estudio de las revueltas civiles y religiosas; y para llevarlas a cabo en menos tiempo dejais la carretera y subís por el atajo. Suprimidos los diezmos, el clero secular español quedará en la misma infelicidad y miseria en la que se hallan actualmente los exclaustrados, es decir, como gazapos en soto quemado, como dijo en otro tiempo el castisimo Gallardo ${ }^{137}$.

Esta mezcla profunda de religiosidad y pragmatismo político es el reflejo de una idea que subyace por doquier en los argumentos carlistas: el integrismo. Los principios políticos y los religiosos están imbricados en un mismo proyecto, apoyándose mutuamente garantizan la pervivencia del poder representado por el Altar y el Trono.

...es tan grande la conformidad de nuestros principios políticos y religiosos, está tan íntimamente unida nuestra causa política con la religión, que no pueden menos nuestros adversarios de caer en el escollo de, o manifestarse faltos de razón, o confesar de plano que nos asiste la razón cuando clamamos contra la impiedad de un partido destructor y enemigo hasta de la misma bondad ${ }^{138}$.

Es interesante apreciar completa esta forma de argumentar, al mismo tiempo en favor de la religión y de la monarquía y lo ilustrativo que llega a ser comprobar cómo, de manera explícita, aparecen ligados en un destino común.

¿Creerá alguno que los Ateos, secta imaginaria en otro tiempo, exista ahora real y verdaderamente en esta desdichada nación bajo el nombre de ilustrados, o ilu-

136 "CirCurar. Sobre el incumplimiento en el pago de diezmos. Cantavieja 28 de septiembre. Félix Obispo de Orihuelas, Boletín del Ejército Real de Aragón, Valencia y Murcia, núm. 73, 30 de septiembre de 1837.

137 «Continuación del discurso sobre diezmos», Boletín del Ejército Real de Aragón, Valencia y Murcia, núm. 52, 19 de julio de 1837.

138 "Plata de las iglesias», Boletín del Ejército Real de los Reynos Unidos Aragón, Valencia y Murcia, núm. 45, 23 de jurito de 1837. 
minados, quienes habiendo tenido la dicha de ser hijos de ella y de haber recibido una educación cristiana nieguen la existencia de Dios por escrito y de palabra cuando hasta la confiesan los Hotentotes, Jos Cafres, los Caribes, los Moros, los Judios y hasta los irracionales? ¿Y será posible creer que muchos buenos Españoles no sólo alternen con los mencionados anticristos, sino que de ellos reciban la ley, y les obedezcan ciegamente? Quítese ya pues el honroso nombre de Católica a España y prívese del título de Cristianos que tanto les ennoblecía a los hijos de ella, que pudiendo no tomar parte en tan heroica y justa lucha, y sepan pues que si permanecen, como hasta aquí serán infaliblemente asesinados por los republicanos, masones, o comuneros que son sinónimos porque todos quieren una misma cosa, cual es acabar con el Altar y el Trono, ahorcando los intestinos del último Sacerdote al último Rey ${ }^{139}$.

Y, después de desautorizar a los políticos liberales, arremete contra los clérigos no carlistas que ponen en cuestión que la apostólica sea la única visión del problema dentro de la iglesia:

¿Cumplen ahora como aquellos defensores de la Religión de eterna memoria los ministros Españoles del Altísimo sin enarbolar el pendón de la fe, permitiendo que se les insulte, que de modo más violento se les precise a salir de sus Claustros, se les despoje de lo suyo, se les prive de todo recurso, se les compela a que se vayan a pedir limosna para que sean el escarnio y el ludibrio de todos, y en fin que se les fusile o asesine? ¿Hasta cuando pues Clérigos y Religiosos, seguireis indecisos prestando una punible obediencia y un criminal tácito consentimiento a ese intruso y usurpador gobierno de la titulada Isabel 2. ? ${ }^{140}$.

Este modo de interpretar la realidad aparecía enfrentado al planteamiento religioso de la Constitución reivindicando en su contra el integrismo como norma del Estado: «adviertase que [en la Constitución] sólo se prohibe el ejercicio público de otro culto que no sea el católico, pero no la profesión del protestantismo, mahometismo, o judaísmo; con lo cual se abrió la puerta a una total indiferencia en materia de Religión; ella comienza por la invocación de la Santísima Trinidad para fascinar más fácilmente a los sencillos" ${ }^{141}$. La concepción dual de la realidad lleva, no tanto a ver como a imaginar cual será el mal frente al bien que ellos representan.

Recórrase toda la Península, y se verán los templos donde ellos han puesto sus pies o saqueados, o convertidos en lugar de prostitución; los monasterios y monumentos más antiguos reducidos a cenizas, los ministros del Santuario, en particular los Regulares asesinados, los prelados echados de sus sillas, a lo menos los que hayan levantado su voz contra los planes de la secta, suprimidos los órdenes religiosos, introducido el cisma, ejerciendo la autoridad en algunos

139 «Un español interesado por el bien de su nación», Boletín del Ejército Real de los Reynos de Aragón, Valencia y Murcia, núm. 41, 10 de junio de 1837.

140 Ibidem.

141 «Conclusión del artículo empezado en el último número», Boletín de Aragón. Valencia y Murcia, núm. 54, 29 de agosto de 1839.

Hispania, LVII/1, núm. 195 (1997) 213-26S 
obispados, gobernadores intrusos contra la voluntad de los legítimos prelados, profanadas las imágenes de Dios y de sus santos, robados sacrílegamente los vasos sagrados, ridiculizadas las ceremonias de la Religión, y arrojado por el suelo el adorable cuerpo del mismo Dios. Pero apartemos la vista de tamaños sacrilegios, cuya relación puede contristar a los piadosos lectores [...]

[...] la grave nación española ve dentro de su seno a los sectarios de Lutero, Calvino, Zuinglio dogmatizando y enseñando sus groseros errores; dentro de poco verá una mezquita, una sinagoga, una pagoda, y aún rabino burlándose de la Religión del crucificado, a un bonzo a un bracmán introduciendo la secta de Confucio... ${ }^{142}$.

En toda esta alucinación el autor no puede dejar de ver la mano del "patriarca de Ferney el blasfemo Voltaire, y de su fiel discípulo Federico de Prusian ${ }^{143}$

La postura de identificar intereses políticos y divinos permite articular sin conflicto la idea de la religión como instrumento para alcanzar objetivos concretos en la tierra. Esto se refleja en cuestiones de poco calado intelectual y desarrollo que, como aquel artículo, defendían que la «religión Católica inflama el valor del militar, lo vuelve más magnánimo, e impide que degenere en ferocidad" ${ }^{144}$. Pero tiene mayor enjundia cuando se presentan las virtudes de la religión como instrumento al servicio de la contrarrevolución. Lo que en tiempos sirvió para derrotar a Napoleón hoy también puede ser válido para dar la victoria a don Carlos. La religión es un instrumento eficaz para obtener la victoria con las armas; "la Religión Católica se alojaba con aplauso en los Campamentos del ejército español, cuando en los de las tropas de Napoleón sólo campeaban el libertinaje, la herejía y la impiedad. Esta Religión celeste era la que inspiraba ánimo y aliento a nuestras tropas que dieron la muerte a cuatrocientos mil enemigos y es la misma que ha hecho acometer empresas arduas y resoluciones atrevidas a los heroicos defensores de la Religión Santa de nuestros padres, y de los legítimos derechos del Sr. D. Carlos 5. ${ }^{\circ}{ }^{145}$.

Desde la perspectiva de la verdad atacada, desde la posición de la defensa de lo auténtico, se ofrece también la imagen de una España católica, auténtica reserva espiritual de Europa para el catolicismo. En esta coyuntura de amenaza aparece el carlismo como la fuerza necesaria para devolver al reino su natural condición.

¡España! ¡Siempre heroica y siempre calumniada España! Entre tus inmarchitables glorias gozas la de que tú sola viste terminar el siglo XVII, sin que esas doctrinas manchasen tu envidiado suelo ni acibarasen tu tranquilidad [...] ¡Dichosísima España! ¿Podrías en el siglo XIX exhibirte al mundo con menos heroísmo que en los anteriores? Entró al fin esa ponzoña en tus recintos. [...] el

142 Ibidem.

143 Ibidem

144 Boletín del Ejército Real de Aragón, Valencia y Murcia, núm. 59, 17 de agosto de 1837.

145 "Continua el artículo anterion, Boletín del Ejército Real de Aragón, Valencia y Murcia, núm. 60,17 de agosto de 1837 . 
mundo observa desde Octubre del año [18]33 los campos de Navarra, Aragón y otras provincias, y recuerda lo que fueron siempre los españoles para su Dios, su Rey y su Patria ${ }^{146}$.

En contraposición se desarrolla un proceso de satanización del liberalismo. Se identifican sus hombres y sus acciones con el peor género de ellos, sin ningún embargo por recrear escenas inverosímiles y de una ficción enfermiza que ya se ha podido apreciar en otros momentos. Este es el comentario que se hace ante la aparición frecuente de noticias en la prensa liberal sobre deserciones en las filas del ejército gubernamental

\begin{abstract}
Entretanto el gobierno inicuo que autoriza asesinatos y sacrilegios, que agradece y premia toda suerte de crímenes, únicos apoyos en que siempre ha estribado, y que toca ya su indefectible aniquilamiento; brama porque a centenares le abandona esa juventud alucinada, miente queriendo obscurecer a los ojos de sus soldados el brillante estado de nuestra causa, y multiplica sus conminaciones, pero toda sin resultados.

Sus soldados ven ya que no son más que crímenes lo que hasta ahora los jefes les recomendaban como virtudes, experimentan únicamente derrotas por donde quiera que son conducidos, y abominando a estos caudillos que los establecieron en instrumentos para la maldad, abandonan con placer esas envilecidas filas en la primera ocasión que se les presenta ${ }^{147}$.
\end{abstract}

$\mathrm{Y}$ en este balanceo constante entre dos extremos representación del bien y del mal, frente al infierno representado por los gobiernos liberales se enarbola la imagen de una Arcadia perdida que fue antes del advenimiento destructor de la revolución. Se recrea de este modo un pasado ideal que ya quisiera para sí la mismísima marquesa de la Rochejacquelein. Un reino inundado de felicidad, donde florecían los negocios y triunfaba la paz bajo la amorosa mirada de un rey-padre preocupado por todo cuanto acontecía a sus vasallos.

...en aquellos primitivos siglos [...] Reinaba por consiguiente entre unos y otros la benevolencia y mutuo amor. De aquí el respeto, obediencia y veneración de los súbditos al superior, de aquí el desvelo, solicitud y afán del superior en promover el bien de todos, de aquí la prosperidad en todos los ramos de la causa pública, la más desembaraza expedición de los negocios y su ejecución, de aquí el florecimiento y duración de la paz.

Que distinto de lo que han traído las luces y la revolución.

Mas ahora que una roncera filosofía blasona de haber abierto los ojos a los hombres, de haber difundido las luces, el progreso de todas las artes, desterrado el

146 «Continúa el artículo del boletín anterion, Boletín de Aragón, Valencia y Murcia, núm. 7 , 4 de mayo de 1839 .

147 «La Redacción», firmado A.A.G., Boletín de Aragón, Valencia y Murcia, núm. 37, de julio de 1839.

Hisparia, LVII/1, núm. 195 (1997) 213-265 
oscurantismo, corregido en su presunción a la misma naturaleza hasta su propio hacedor; si hubiéramos de decir que es gobierno popular, responderíamos sin titubear ni temor de equivocarnos el mundo al reves, un caos, un abismo, un tragadero de sangre y de vidas, un respiradero de muerte: verdad tan de bulto, que nos está dando instantáneamente en los ojos, y tropezamos con ella hasta con los pies de carne desde su infernal introducción.

Corrientes de lágrimas, ayes y lamentos incesantes, hacinamientos de huesos humanos, montes de cenizas, ciudades reducidas a escombros y soledad, despojos en manos de asesinos y sicarios fluyéndoles hilo a hilo el sudor ajeno, extenuadas madres asomándoles el pasmo y dolor en vez de las agotadas lágrimas, crueles sátiros escarneciéndolas con amargas ironías, esqueletos ambulantes, plumas embebidas en hiel de áspid, Nogueras, Van-Halenes, Narvaeces, Quesadas, Minas oprimiendo moribundos soldados en sus propios lechos, desgarrando criaturas vivas de abajo arriba, arrancándolas hasta del útero de sus parturientas madres; últimamente estanques de sangre, silencio sepulcral y muerte, y una estulta dama paseando su vista bailarina y cantatriz sobre este universal espectáculo al que ella le abrió la puerta; serían los colores con que debieramos cubrir el lienzo. Hete el gobierno popular ${ }^{148}$.

En definitiva, todas las ideas que giran en torno al tema de la Religión desarrollan una defensa de ésta que es sólo la antesala de la verdadera lucha, devolver a la Iglesia todo su poder e influencia perdidos. Sólo de ese modo tiene sentido considerar a la iglesia como el apoyo del trono, a partir de la reposición de todo el poder que tradicionalmente había dispuesto en el contexto de la monarquía absoluta.

\section{La monarquía católica}

El pensamiento político carlista vertido a través de su prensa oficial está producido prácticamente en su totalidad por religiosos, con una formación intelectual, una retórica de seminario mayor y muy poco contacto, ni voluntad de él, con las doctrinas ilustradas. Eclesiásticos son los directores de la imprenta de Mirambel y también el director del Boletín, así como muchos de los colaboradores cuyos artículos aparecen firmados. Por eso, los argumentos religiosos desbordan las áreas estrictamente dedicadas a la religión impregnando cualquier aspecto de la especulación política. Es la consecuencia más evidente del integrismo que planea sobre el conjunto de las ideas. En esta línea se desarrolla una defensa de la monarquía absoluta, sin concesión ni pacto alguno.

La filosofía moderna respeta tan poco a las potestades del siglo que o bien les niega toda autoridad, o si les deja a los soberanos el manto real, le corta tantos pedazos, que ya no puede servir ni para su adorno, ni para cubrir su desnudez.

I48 «Q中é es gobierno popular?», Boletín de Aragón, Valencia y Murcia, núm. 29, 27 de junio de 1839.

Hivpania, LVI1/1, núm. 195 (1997) 213-265 
Rousseau en su decantada fábula del pacto social sembró el germen de las revoluciones: la Francia, la España, Napoles, Portugal, el Piamonte y las Américas han cogido los frutos de tan funesta semilla: frutos a la verdad bien amargos: ¿pero quién es el necio que los busca dulces en el árbol mortífero de la filosofía? Las inquietudes del estado nunca están muy lejos de las de la Iglesia, y el que ha llegado a sacudir el yugo de la fe, tampoco respeta el de las potestades del siglo. ¿Cómo ha de respetar el filósofo a las potestades, que dimanan de Dios, no respetando a la misma Majestad divina? ${ }^{49}$.

Sin embargo, como no podía ser de otro modo, las causas de la debilidad de la monarquía proceden de los ataques recibidos por la religión que, habiéndose debilitado, no había podido impedir que las siguientes andanadas dañaran directamente al trono.

La herejía de Lutero sublevó la Inglaterra contra Carlos I que balanceaba entre el protestantismo y catolicismo, y la filosofía moderna ha sublevado la Francia contra Luis XVI. Rey cristianísimo. Entrambos monarcas, perdieron la corona y la cabeza a manos del verdugo en la plaza pública de sus mismas capitales, entre los insultos de un pueblo fascinado. Jamás hubieran tenido lugar unas escenas tan tristes, si la herejía y la filosofía no hubiesen roto primero los sagrados vínculos de la Religión; pero una vez roto este primer anillo de la sociedad, el corazón de los súbditos fácilmente se desprende del monarca y se debilita su autoridad ${ }^{150}$.

"Genios infernales que embriagados con el cáliz mortífero del ateísmo y anarquía, redoblais atrevidos los esfuerzos para derribar si fuese posible el Altar y el Trono del digno sucesor de San Fernandon is!. Así clamaba un artículo destinado a defender las virtudes del Altar y el Trono aventurando una restauración de la primacía de ambos, sostenida sobre el providencialismo. "Aquel Dios de los Ejércitos, cuya existencia negais en vuestro negro corazón, protege visiblemente la noble causa de la Religión y de la legitimidad que son causas suyas".

El modelo social defendido es el estamental apoyado en un sector de privilegiados - nobleza y clero- que no puede confundirse con la «infame plebe» ni siquiera en su tratamiento como simples seres humanos, algo que se refleja en esta apreciación: «El noble, el respetable clérigo y el virtuoso monje han sido confundidos con la infame plebe, y hacinados en una misma cárcel o presidio con el infame ladrón y el vil asesino, y han sido fusilados o han sufrido la pena de garrote indistintamente" ${ }^{152}$. Y al interpretar cuales eran los baluartes sobre los que debieran haberse defendido los principios de

\footnotetext{
149 Firmado por «el Español», Boletín del Ejército Real de Aragón, Valencia y Murcia, núm. 74,7 de octubre de 1837 .

150 Ibidem.

151 Boletín del Ejército Real de Aragón, Valencia y Murcia, 10 de marzo de 1838.

152 «Continua el artículo anterion, Boletín del Ejércifo Real de Aragón, Valencia y Murcia, núm. 101,10 de enero de 1838.

Hixpania, LV]L/1, núm. 195 (1997) 213-265
} 
la monarquía absoluta frente a la revolución postula en estos términos: "...el Clero, los Magistrados, la Nobleza y los empleados en los distintos ramos del reino, junto con los sabios literatos podían formar una barrera que tal vez hubiera contenido la revolución en sus principios...» 153 . Para los estamentos no privilegiados no hay función en el Estado, pero pueden estar satisfechos porque se hallan en los dulces brazos de un monarca paternalista repleto de inspiración católica que hace la felicidad de sus súbditos. «Si nosotros somos más felices, si gozamos de las dulzuras de un gobierno paternal, no es a las sectas, ni a la filosofía, sino a la Religión católica a la que debemos este bien incalculable» 154 .

Para concluir con las ideas que se articulan en torno a la monarquía es particularmente valioso considerar la función destinada a la Religión como educadora tradicional de las almas de lo súbditos de las monarquías. Esta enseñanza estaba orientada a educar en la sumisión al trono. «Si la religión del crucificado fundada sobe la humildad abate el orgullo de los príncipes y poderosos de la tierra, también podemos decir de ella con verdad, que ha aparecido en el mundo para consolidar los tronos y el respeto debido a las potestades $i \mathrm{De}$ quién sino de la Religión católica han aprendido los pueblos la sumisión, la paciencia, el respeto y la obediencia debidas a las legitimas autoridades?»155. El hombre, por naturaleza tiende a la independencia y secunda con facilidad los proyectos de insurrección contra el poder ${ }^{156}$. A esto pone remedio la religión educando a los católicos en la sumisión al poder establecido.

La Religión católica es la que ha inspirado a los hombres que debemos reverenciar en todos los príncipes de la tierra, tales como sean, el orden del cielo y el carácter del Todopoderoso. Enseñando a los fieles que el poder de los soberanos no les viene del convenio de los hombres, ni del beneplácito de los pueblos, sino del mismo Dios, les persuade que su divina ordenación es el fundamento primero y universal de todos los derechos del soberano, sin la que ningún Rey $\mathrm{ni}$ superior alguno tendría en la tierra otro derecho para obligarnos a obedecerle que la bárbara ley del más fuerte.

Y se expresa con nitidez el fundamento teocrático de la monarquía concebida por el carlismo dejando también a la luz un importante matiz instru-

\footnotetext{
153 «Concluye el Artículo anterion,, Boletín del Ejército Real de Aragón, Valencia y Murcia, 14 de febrero de 1838 .

154 «Sigue el artículo anterion, Boletín del Ejército Real de Aragón, Valencia y Murcia, 17 de marzo de 1838.

IS5 «Es la Religión católica la que más ha consolidado los tronos de los monarcas y el respeto debido a las potestades», Boletín del Ejército Real de Aragón, Valencia y Murcia, 7 de abril de 1838.

156 «El amor a la independencia es tan natural al corazón del hombre siempre altanero y orgulloso que no puede dejar de repugnarle la sujeción. La obediencia ha sido en todos tiempos un yugo pesado a los hombres. [... La revolución impía que llena hoy la España de Sangre y de ruinas nada puede ofrecer de consolante al hombre sensato: pero tiene el secreto atractivo de levantar partido contra el poder legítimo; y no hay que dudarle, en esto ha consistido una gran parte del misterio de su atracción». Ibidem.
} 
mental de la religión para obtener el sometimiento de los pueblos al poder político: «La doctrina y el ejemplo de J. C. juntamente con las palabras del Apóstol han hecho que los pueblos reconociesen en los soberanos la imagen de Dios, y en la voluntad del Monarca la voluntad de Dios Mismon 157.

Y a la inversa, la educación que la Iglesia había difundido entre los fieles era la mejor salvaguarda que podía ponerse al desarrollo de veleidades revolucionarias. No hay mejor antídoto contra la revolución que una comunidad de católicos sumisos a Dios y obedientes a su Iglesia. Lo prueba "...que jamás se habia visto un solo cristiano complicado en las revoluciones de su siglo: en todos tiempos, y en todas las naciones los soldados católicos se han distinguido siempre por su fidelidad» 158 . «La Iglesia católica jamás se ha separado de la doctrina de San Pablo, el mayor defensor de la autoridad de los Reyes», mientras que la «irreligión ha sido siempre la que ha preparado el camino a las revoluciones, pues el estandarte de la impiedad es el que reúne a los conspiradores contra el trono». De ahí que «...han sido muy raras las revoluciones en los paises católicos". "Así es, que en los anales de las monarquías católicas apenas se halla un solo Rey entre ciento que no haya procurado merecer el amor y la gratitud de sus vasallos con actos públicos de clemencia [...]. Estas reflexiones que los ministros de la Religión predican todos los días a los fieles, son las que les inspiran el respeto, y las que estrechan los lazos de los súbditos con los soberanos, y de los pequeños con los grandes; pues si por desgracia llega a faltar la Religión se deshacen luego estos lazos, y faltan en los pequeños el respeto, la sumisión y la obediencian 159.

\section{Et liberalismo, sistema perverso}

El liberalismo fue el rostro que, a ojos de los carlistas, tenía la revolución en España. En consecuencia, el carlismo, como ideología fundamentalmente contrarrevolucionaria que era, se ocupó de levantar un auténtico entramado de ideas negando cualquier virtud a los principales aspectos del liberalismo y propagando toda una serie de atributos peyorativos con ánimo de construir una patética estampa de éste. La imagen carlista del liberalismo fue una de sus piezas más trabajadas, hasta el punto de que puede considerarse como el objetivo central de la producción ideológica contrarrevolucionaria en España.

Una de las lagunas que siempre tuvieron los escritores políticos carlistas fue la de comprender como se había producido de forma concreta el acceso de los constitucionales al poder. Se apuntaron diversas interpretaciones sobre el hecho, pero la realidad era que ninguna de ellas resultaba definitiva y la incomprensión del hecho resultó lo único evidente. Por eso prosperó una teo-

\footnotetext{
157 «Es la Religión católica la que más ha consolidado los tronos de los monarcas y el respeto debido a las potestades», Boletín del Ejército Real de Aragón, Valencia y Murcia, 7 de abril de 1838.

158 «Continua el artículo anterion, Boletín del Ejército Real de Aragón, Valencia y Murcia, 11 de abril de $\$ 838$.

159 Ibídem.

Hispania, LVIL/1, núm. 195 (1997) 213-265
} 
rá conspirativa como fórmula para comprender los avances de la revọlución. Los liberales habían llegado al poder como resultado de los manejos de una organización sectaria y, por lo tanto, el asalto había sido obra de unos pocos iniciados sin apoyo en la sociedad.

Cuando al primer golpe de su traición, se apoderaron de todos los recursos del Estado, creyendo imposible que ya la legitimidad pudiese llegar a contrarrestarles, se propusieron el exterminio total de cuantos no estaban iniciados en su tenebroso plan. Sus primeros ensayos de barbarie obligaron a varios fieles a levantar el grito de Religión, Patria y Rey que se miraba perseguido y vilipendiado todo en obras y palabras las más impías. Más como con respecto a su poder usurpado, eran estos insignificantes, decretaron guerra a muerte, que con horror del mundo entero practicaban y han practicado, no sólo con los que se declaraban, sino tambien con cuantos encontraban en el campo por donde habian pasado, y en las casas masías donde habían estado aquellos héroes de la legitimidad. Por todas partes resonaban el terror, y el funesto acento de la muerte ${ }^{160}$.

Las explicaciones de indole conspirativa se mezclaban con otras apoyadas en la degradación de las costumbres por efecto de las influencias extranjeras. Cualquier adaptación a Espan̄a de cuanto se había experimentado en regímenes políticos europeos era rechazado por principio ${ }^{161}$. Y se planteaba una secuencia muy clara de cómo la adopción de usos franceses había llevado hacia la degradación de las costumbres y permitido el acceso de la revolución. En el inició una "galomanía se apoderó insensiblemente de una gran parte de los españoles, en especial de las clases más distinguidas; modas, trajes, comidas, teatros, bailes, libros y de consiguiente las costumbres, todo respiraba un aire francés. Los trajes españoles daban un cierto aire de gravedad a las personas que los vestían, que no podía dejar de chocar al genio bullicioso del siglo filosófico" ${ }^{162}$. En todo ello se reconocía la mano del «impío Mirabeau», tan moderado, por cierto, en sus planteamientos. La conspiración siguió avanzando a través de este canal de desintegración. "Una fatal libertad se introdujo en la juventud de entrambos sexos» ${ }^{163}$. Era la consecuencia que

160 Boletín del Ejército Real de Aragón, Valencia y Murcia, 17 de octubre de 1838.

161 "Dejamos dicho que los revolucionarios no se cansan de repetir que nuestra nación no puede ser feliz sino bajo el dominio de su exterminador sistema. Inglaterra y Francia son la prueba concluyente que creen darnos estos estúpidos maquinadores. No debe ser de nuestro objeto examinar si esas naciones gozaban más o menos felicidad cuando eran monarquias completas. [...] Vosotros con quienes ese puñado de fieras ha formado la alucinada minoría de España, os hallais fascinados con la financiera opulencia de Inglaterra y de otras naciones, y vuestros embaucadores os repiten con énfasis que es milagro obrado por la democracia. [...] Hijos de lberia: nuestro Boletín no se cansará de demostraros que cualesquiera que sean nuestros adelantos en las ciencias y en las artes, por fa mayor parte desconocéis una verdad sencillísima y que inmediatamente afecta vuestros principales intereses, esto es: que las leyes humanas degeneran en su irasplantación». «Continúa el articulo anterion», Boletín de Aragón, Valencia y Murcia, núm. 12, 16 de mayo de 1839.

162 Boletín del Ejército Real de Aragón, Valencia y Murcia. 3 de febrero de 1838.

163 Ibiden. 
cabía esperar de aquella filosofía que no rechazaba los sentimientos y abría las puertas a la sensibilidad permitiendo la entrada a una irrefrenable avalancha de senstaalismo cuyas consecuencias eran imprevisibles. «El inmortal Cervantes, con su famoso don Quijote, había desterrado de España los libros de caballerías; más el espíritu del mal ha sabido sustituirles [por] las novelas amorosas, que han sido la peste moral de nuestra juventud, y de las que pueden decirse con un poeta romano, que son unas historias que enseñan a pecar» 164.

Se presentaron al público lo que serían los planes de la secta filosófica, según los cuales, una vez derribada la religión, todos los males se abatirian sobre el reino.

Destruidos los fundamentos sobre los que estriban la alta dignidad y noble origen del hombre, pospuesto Dios, su divina Religión, la sumisión y obediencia debida a sus vicerregentes en la tierra; se hacía fácil abrir ancha puerta a las crecientes y avenidas que arrastraran al hombre y le sumieran en el cenagal y revolcadero de la más rematada impiedad, de la blasfemia, de la bestialidad, de la desenfrenada lujuria, del robo, del asesinato, del escarnio de sus propios padres, de toda fraudulencia, canonizadas todas estas monstruosidades con el venerable nombre de virtud ${ }^{165}$.

Y como este objetivo era demasiado radical para ser obtenido sin el engaño se fue preparando el camino a través de diversos maestros que, con sus doctrinas abonaron el terreno hasta obtener un fin semejante:

Era no obstante este demasiado salto para hacerlo dar de una vez al hombre imbuido y habituado a doctrinas y prácticas más sublimes ¿Qué pues? dorarle el tósigo y hacerle puente con las seductoras perspectivas de filosofía, de libertad, y luego de libertinaje [...] Entraron a preparar el camino el sombrío Hobbes, el hediento Pufendorf, el osado Barbeyrae, el desalmado Locke, el cerril Leclerc, el peor de todos éstos, si peor hay entre ellos, el judío hereje Spinoza, bisabuelo de Mendizábal, hasta que del contínuo acceso de éstos, digámoslo así, con la fornicaria de Babilonia nos arrojaron al mundo, a los dos dragones de las colas humeantes, monstruos gemelos los dos, Voltaire y Rousseau, que con la procacia de la madre tigre que mamaron, con los embeleços y hechicerías de sus sarcasmos y ridículo para desgracia del linaje humano, consiguieron la detestable satisfacción de introducir toda su malicia en los pechos de la siempre novelera y veleidosa Francia ${ }^{166}$.

Cuando no se presentó el liberalismo como un sendero degradante hacia la perversión de las costumbres y las gentes, se puso énfasis por mostrarlo como el sistema político que proclamaba la anarquía. Esto se reflejaba en las tres ciudades de la Corona de Aragón donde habían cobrado mayor arraigo Ios movimientos revolucionarios. "En cada una de estas tres famosas capitales del Reino de Aragón [Zaragoza, Barcelona y Valencia] hallarás un precipi-

1 is Ibídem.

I65 Boletín de Aragón, Valencia y Murcia, núm. 23, 13 de junio de 1839.

I6́ Boletín de Aragón, Valencia y Murcia, núm. 23, 13 de junio de 1839.

Hispania, LVII/I, núm. 195 (1997) 213-265 
cio. Todas son ya Madrid en el desorden y anarquía: en todas dominan las luces de la Nación, los hombres inmorales, los ladrones y asesinos, los hijos de la revolución sin probidad y sin principios» 167 .

Si por un lado el liberalismo había entronizado la anarquía como sistema político, por otra parte era presentado como el paradigma del ateísmo. No es indiferencia hacia la religión sino militancia activa contra lo divino lo que se atribuye a los seguidores del gobierno constitucional. Con motivo de la consagración de la Iglesia arciprestal de Morella se vertían estos comentarios en los que se manifiesta la concepción del ateísmo liberal frente a la profunda religiosidad carlista:

Los fieles morellanos que por el largo espacio de cuatro años no habian presenciado más que insultos, multas, cárceles; destierros y espectáculos de sangre mezclados con los escándalos, irreverencias y burlas abominables de todo lo sagrado, singularmente en los días solemnísimos de la Semana Santa, han tenido la satisfacción de poder observar el contraste entre nuestras tropas y las del gobierno intruso, contraste no menos honroso para las tropas de la fidelidad, que ignominioso para las de la usurpación. Cuando en los pasados años los soldados de la impiedad, haciendo alarde de su irreligión, singularmente los lla mados oficiales, en las tinieblas de estos tres días, a golpes de mazos hacían astillas los confesonarios, en el presente han visto arrodillarse a los pies de un Sacerdote en estos lugares de reconciliación a los beneméritos militares; que llenos de piedad y de compunción le pedían humildemente la absolución de las fragilidades en que habían tenido la desgracia de caer ${ }^{168}$.

La evidencia de que las fuentes intelectuales en las que bebía el liberalismo procedían de la Ilustración europea, y francesa particularmente, llevó a atribuirle un carácter antinacional. De este modo, los carlistas se apropiaron del papel de defensores de los intereses nacionales y mostraron como incomprensible que existieran seguidores para un partido que no miraba sino por el beneficio personal. «Infelices! ¿Será posible que continúen dejándose guiar como carneros por cuatro pedantes egoístas, a quienes tanto interesa vivir en España como en Francia?» 169 , clamaban manifestando su incomprensión ante el hecho.

Otras de las vías de ataque al liberalismo consistí en asestar golpes a sus principales instituciones o principios rectores, bien ridicudizándolos 0 poniendo en cuestión que fueran movidos por un sano interés. Se identificó a las instituciones constitucionales como «la reunión de una gavilla de farsantes asalariados, con la presencia de una huérfana» ${ }^{170}$. La providencia tenía

\footnotetext{
167 «Pasaporte para el nuevo Boletin del Ejercito Real de los Reynos de Aragón, Valencia y Murcian, Boletín del Ejército Real de Aragón, Valencia y Murcia, núm. 48, 5 de julio de 1837.

168 Boletín del Ejército Real de Aragón, Valencia y Murcia, 14 de abril de 1838.

169 Boletín del Ejército Real de los Reynos Unidos Aragón, Valencia y Murcia, núm. 44, 21 de junio de 1837.

170 «Otro de los rebuznos del patriota », Boletín del Ejército Real de Aragón, Valencia y Murcia, núm. 40, 12 de julio de 1837.
} 
destinada a los carlistas la misión de acabar con ellos. «España [...] está efectivamente destinada por la Providencia a dar grandes ejemplos al mundo; pero no de amor a esas abominables instituciones que nos inculcas, sucio Patriota, sino de odio a cuanto tenga relación con ellas, y decisión por cuanto os arranque de la cabeza el delirio liberal y os confunda para siempre» 171.

En esta línea conviene seguir profundizando. La estrategia de ataque a los principios y las instituciones liberales, tiene dos ramificaciones muy desarrolladas: el rechazo de la libertad de imprenta y la crítica de la pluralidad politica.

1. En el contexto de la monarquía absoluta la Iglesia había tenido el monopolio de las ideas merced a que el Estado delegó en ella las funciones de control ideológico que ejerció con eficacia mediante instrumentos como los indices y las juntas de censura. De este modo política, religión, filosofía, ciencias o literatura quedaban sometidos a censura previa y bajo el criterio eclesiástico. Copado el campo institucional por la represión, aunque el "contrabando" de libros e ideas no fuera insignificante sus posibilidades de desarrollo fueron muy reducidas y los detentadores del poder ideológico debieron sentirse satisfechos del grado de control que ejercían sobre el total de la producción intelectual.

La introducción de la libertad de prensa dio al traste con esta situación. Desmanteló todo el mecanismo de control y sólo quedaron unas rémoras menores para los escritos que trataran temas religiosos. De ahí que la alibertad de la imprenta debe ser temida como la artillería gruesa, de la que se sirve la filosofía para batir en brecha los muros de la Religión y de la Monarquía, o como las bombas que dispara la revolución para arruinar las ciudades» 172.

La libertad de imprenta es la representación política de la libertad ideológica y esta se enfrenta radicalmente con el paternalismo infantilista que servía al carlismo para comprender sus relaciones con la nación. Las lecturas inconvenientes tenían, en manos del pueblo inmaduro, efectos devastadores:

Son muchos los incautos que empiezan a leer los libros pésimos no más que por vanidad o movidos de una curiosidad imprudente y temeraria, pero luego toman gusto al estilo y a las gracias del autor, y concluyen regularmente por abrazar sus jdeas.

Las Comedias, las Novelas y Romances obscenos fomentan la lascivia y desmoralizan la juventud; los libros impios hacen perder la fe y la Religión a muchos de sus lectores y los escritos sediciosos enseñan doctrinas subversivas del orden y provocan los pueblos a la revolución. [...] Si cada uno tiene libertad para escribir cuanto quiera serán fatales los resultados. A esta licencia de imprenta debe el mundo moderno la corrupción general que tanto le deshonra, los fieles la tibieza en la Religión de sus padres, que se aproxima a una verdadera indiferencia, y los pueblos las revoluciones que los acaban ${ }^{173}$.

\footnotetext{
171 Ibidem.

172 «Libertad de imprenta», Boletín del Ejército Real de Aragón, Valencia y Murcia, núm. 65, 6 de septiembre de 1837 .

173 Ibídem.

Hispania, LVII/I, núm. 195 (1997) 213-265
} 
Las gentes sin formación carecían, como individuos perpetuamente infantiles, del discernimiento para tomar decisiones adecuadas, de modo que fue realizada por ellos la labor de seleccionar lo que era adecuado saber y conocer, e incluso lo que debían pensar. Una disposición de la Real Junta de Aragón Valencia y Murcia pone de manifiesto su planteamiento político en este punto. Ordena se impida «la circulación de sus Folletos para que la sencillez, y buenas costumbres no se resientan con una lectura siempre peligrosa a los que no se hallan con el discernimiento necesario a la calificación de las doctrinas revolucionarias que encierran, y depravados fines que se proponen. En consecuencia pues ha tenido a bien acordar se prohiba en estos Reinos la circulación de perí́dicos Folletos y toda clase de papeles públicos del gobierno revolucionario usurpador bajo la multa de 50 ducados» 174 . Y esta concepción de la sociedad inmadura alcanza su grado más alto en los momentos que se indica cual debe ser la actitud de las mujeres. Satisfechas debieran estar las mujeres de una religión que les proporciona tanta libertad y les ofrece toda su consideración, y no como otras religiones que existen en el mundo que son opresivas e inhumanas. De modo que si «el tiempo que malgastais en la lectura de novelas amorosas y tal vez impías, lo empleaseis en leer las historias de las naciones idólatras antiguas y modernas, o de aquellas que se gobiernan por las leyes del Alcoran de Mahoma, no sabríais agradecer bastante a nuestra Religión Santa los grandes beneficios de que le sois deudoras» 175 .

En la libertad de imprenta se halla contenida la libertad de prensa sin coacción, y este pensamiento expedito atemorizaba a cualquier ideólogo contrarrevolucionario porque quedaba abierta la vía para que el individuo pudiera construirse a sí mismo, sin preceptores imperativos que acotaran los campos de la razón y del sentir. «Si es un delito el robar, los bienes a un vecino, o el seducirle la mujer o deshonrarle la hija ¿no será un crimen mucho más detestable encender la llama amorosa y la avaricia, y despertar en los corazones de la juventud la pasión de la lascivia por medio de los libros inmorales y obscenos?" ${ }^{176}$. Toda una tiema, e involuntaria, metáfora de los accesos que el librepensar podía franquear hacia parcelas de la realidad que hasta el momento habian quedado vedadas. Por ser una puerta hacia el individuo. la libertad de prensa fue contemplada por los ideólogos contrarrevolucionarios como una vía directa para la disolución de la Religión y la Monarquía, tal y como estaban concebidas en el Antiguo Régimen. "La España ha experimentado bien a su costa todos los males que la prensa puede causar a un reino, cuando se le concede una libertad democrática y atea; ha conocido bastante que es una fiera cruel y temible, y desea verla atada con gruesas cadenas y aprisionada con grillos y esposas de aceron ${ }^{177}$.

\footnotetext{
174 Mirambel, 12 de junio de 1838, firmado por el Conde de Samitier. Boletín del Ejército Real de Aragón, Valencia y Murcia, 20 de junio de 1838.

175 Boletín del Ejércilo Real de Aragón, Valencia y Murcia, 17 de febrero de $\$ 838$.

176 «Libertad de imprenta», Boletín del Ejército Real de Aragón, Valencia y Murcia, núm. 65, 6 de septiembre de 1837.

177 bídem.
} 
Desde la posición del dirigismo ideológico que practicaba el carlismo había una circunstancia que se hacía incomprensible e inaceptable: que existieran dos o más opiniones sobre un mismo asunto que afectara al gobierno. Así, es incomprensible que la acción del gobierno pueda ser criticada por individuos que aceptan el sistema o que se empleen los periódicos para mostrar la discrepancia política en lugar de la unidad de criterios:

En resumen: cada periódico de ese partido exterminador generalmente no es otra cosa que una continuada, interminable y justa acusación fiscal contra todos los ministros y corifeos que ha tenido la usurpación de Madrid. ¡Pero que acusación! ¡que pruebas tan inconcusas! jque descubrimientos! que manejos tan infames sacados a luz! ique demostraciones tan incontestables de que tienen para caudillos unos ladrones envueltos en otros muchos crímenes!.

Se sabe, que todos los adalides de la usurpación son escritores o dueños de periódicos, y nosotros repetimos, que calificándose ellos mutuamente, y con tanta justicia y escrupulosidad, poco o nada nos dejan que hacer. ¡Cuanto se lo agradecemos! ¿qué más podemos decir nosotros? El latrocinio y la traición cobijadas con las especiosas palabras de patriotismo, ilustración y otras semejantes, son la base de conducta de todos ellos ${ }^{178}$.

Esto no es extraño, puesto que el razonamiento contrarrevolucionario se establecía a partir de una verdad única y monopolizada por el poder, y no podía comprenderse que existieran diversas interpretaciones de la realidad $\mathbf{y}$, lo que era más importante, que se hicieran públicas rompiéndose el monopolio de la verdad difundida.

2. El ataque contra las instituciones liberales que se despliega desde posiciones contrarrevolucionarias se dirige particularmente contra los representantes populares de la nación, a quienes se presenta como meros individuos pugnando por sus propios intereses en un ambiente de indignidad. Para ello se parte también de la contradicción que tiene con los principios carlistas la existencia de diversas posturas frente a los hechos, ofreciendo una imagen de enconamiento y desorden en los mismos puntos donde el liberalismo situaba los soportes del sistema. «Periodistas contra periodistas, diputaciones provinciales, ayuntamientos constitucionales, todos estos de motín contra si, y ellos mismos contra los generales, contra los ministros y ministerios presentes, pasados y futuros, contra sus clubs cámaras constituídas, o constituyentes, en ejercicio, suspensión o disolución, contra la misma idolatrada inocente, contra su merecidamente ultrajada Mamá,...» ${ }^{179}$.

Y como si fuera una sublimación de este enfrentamiento esencial que afecta al país, merece especial atención la división de partidos. "Tres son los partidos que nos dividen, y que luchan en la arena por el supremo poder: el de los bullangueros exaltados, el titulado de los moderados 6 del justo medio, y el de los leales carlistas. Los dos primeros pertenecen a la revolución, y aspi-

178 «Revista de periódicos revolucionarios», firmado A.A.G. Boletín de Aragón, Valencia y Murcia, núm. 16, 25 de mayo de 1839.

179 Boletín de Aragón, Valencia y Murcia, núm. 13, 18 de mayo de 1839.

Hispania, LVII/I, núm. 195 (1997) 213-265 
ran al mismo fin, aunque por medios al parecer opuestos. Lejos de haberse conciliado los dos contrarios partidos de exaltados y moderados con el farnoso sermón de las tres palabras que predicó el almibarado Martínez de la Rosa en una sesión de cortes, y cuyo objeto eran el orden, la paz y la justicia se han encendido más el odio y rencor que naturalmente se profesan" ${ }^{180}$. El objetivo al que va destinado un planteamiento en términos de enfrentamiento visceral entre los partidos parlamentarios era siempre el mismo, mostrar «la guerra encarnizada que se hacen mutuamente exaltados y moderados; jovellanistas y americanos; cristinos puros del despotismo ilustrado, y cristinos mixtos del estatuto de la constitución; las miserables intrigas de una corte bastarda; la nulidad de la titulada Regenta que siente una cosa en la camarilla, y resuelve otra en el despacho con sus ministros» ${ }^{181}$.

Se muestran por separado, y uno en relación al otro, los dos partidos y su perversión alcanza tal grado que es difícil discernir cual despierta mayor odio entre los carlistas. Sobre el partido moderado afirman: «El partido liberal moderado, como falsamente se titula, es el principal autor de nuestras desgracias, el más inexorable promovedor de escenas sangrientas, el más astuto inventor de toda clase de medios de seducción, el más pérfido en sostenerse, valiéndose para conseguirlo de cualesquiera engaños, ficciones y embustes, el mas odioso por la infamia de sus maniobras ocultas, y el más terrible por su audaz hipocresía 182. Difícil perdonar al moderantismo la plataforma que proporcionó al régimen mediante su desplazamiento aperturista que permitiera el entendimiento con los sectores más próximos del liberalismo. "Como Quiera que sea, es indudable que a los hipócritas jovellanistas es a quienes únicamente debe doña María Cristina haber conservado hasta ahora el título de reina gobernadora; no porque la amen, sino por aquel todavía no es tiempo, nosotros queremos lo mismo, pero esperamos ocasión más oportuna. que forma la base de su doctrina y su manifestación a las otras fracciones del bando liberaln 183 .

Las criticas del moderantismo nunca podrían derivar en elogios del partido exaltado que para el carlismo constituye el todo. «Entre las infinitas divisiones y subdivisiones que ha tendido el partido liberal, se levantó esa bandería jovellanista que tiene alborotado todo el país que domina la revolución y que ocupa casi completamente las columnas de los periódicos de la anarquí, pretendiendo dominar a las demás» ${ }^{184}$. Por ello los exaltados son sítuados más allá de la lucha por el control de la prensa y sus esfuerzos por

\footnotetext{
140 "Dialogo entre el tío Roque arriero del pueblo de Buenaire, y el boticario del mismo». Boletín del Ejército Real de Aragón. Valencia y Murcia, 2 de junio de 1838.

${ }^{181}$ Boletín de Aragón, Valencia y Murcia, núm. 7, 4 de mayo de 1839.

182 «Dos palabras del Boletín a los SS. del partido liberal moderadow. Boletín del Ejército Real de Aragón Valencia y Murcia, 6 de junio de 1838.

${ }_{183}$ La cursiva procede del original. «La redacción. Concluye el artículo inserto en nuestro número 40m. Boletín de Aragón, Valencia y Muncia, núm. 42, 30 de julio de 1839.

184 «La redacción. Tentativas de los revolucionarios exaltados para arrancar a la reina viuda su nominal regencià, Boletín de Aragón, Valencia y Murcia, núm. 40, 23 de julio de 1839.
} 
asentarse en el poder reciben la consideración de manejos conspirativos. "Entretanto, los exaltados no perdonan recurso ninguno para arrebatar las elecciones a los jovellanistas. El infernal directorio masónico de Madrid envía emisarios a todas las provincias para que con los súbditos que en ellas tienen, maquinen infatigables a fin de contrarrestar los manejos jovellánicos» 185 .

Pero estos esfuerzos por establecer diferencias se producen sólo para diseccionar mejor el sistema liberal y mostrar que la perversidad de su naturaleza llegaba a todos los rincones. «En el Salón de las cortes se dijo públicamente que exaltados y los del justo medio todos tienen un mismo fin, que es hacer que deje de vivir en España, el árbol de la religión, sólo que los primeros requieren que muera a golpe de la segur, y los segundos a fuerza de la sequía o falta de riego" ${ }^{186}$. Y teniendo en cuenta los infames objetivos que aúnan a ambos partidos, los procesos electorales son ejercicios que ningún católico puede aprobar, lo que parece llevar directamente a la negación de la soberanía nacional.

¡Que compromisos para los votantes (serán los más) a quienes uno y otro partido exijan el voto indefectiblemente! ¡Cuantos electores quisieran no serlo! ¡Que pocos habrá a quienes al tiempo de entregarles la lista de las personas que han de favorecer con su voto, no se les enseñe el puñal o la pistola! ¡Cuantos templos no serán violados con sangre humana!

Ved ahí, pueblos, ved ahí españoles la soberanía nacional que se ofrece; ved ahí el acto de nombrar representantes tan repetidamente llamado solemne, y que nosotros apellidamos ridículo, sanguinario y profanador al menos por lo que hace a España; ved la libertad que se os ofrece para emitir vuestros votos, y nombrar para que os representen a quienes creais más dignos; ved la legitimidad de esta llamada representación nacional; ved en fin la perfidia con que estas infames pandillas se sirven de vosotros para dominaros, y extraeros el pan de vuestros hijos, y los productos del sudor de vuestras frentes ${ }^{187}$.

En suma, la ideologfa contrarrevolucionaria desarrolló una doble estrategia en su producción para desautorizar al liberalismo: la caracterización mediante atributos negativos y el ataque a los principales soportes del sistema, particularmente a la libertad de prensa y a las reglas del juego parlamentario. Todo lo cual permite considerar los cambios operados en la forma de gobierno de España como negativos e innecesarios.

¿Cuántos son los progresos que ha hecho la España desde aquel tiempo al nuestro o en qué consiste ésa tan decantada ilustración? Mientras aguardamos la respuesta, que no vendrá, contestaremos nosotros y diremos: la ilustración y los

\footnotetext{
185 «La Redacción», firmado A.A.G., Boletín de Aragón, Valencia y Murcia, núm. 39, 20 de julio de 1839.

186 «Dos palabras del Boletín a los SS. del partido liberal moderado». Boletín del Ejército Real de Aragón, Valencia y Murcia, 6 de junio de 1838.

$1 \times 7$ «La Redacción», firmado A.A.G., Boletín de Aragón, Valencia y Murcia, núm. 39, 20 de julio de 1839.
}

Hispania, LVI1/1, núm. 195 (1997) 213-265 
progresos que hemos hecho en ella consisten en que en aquel tiempo eran respetadas las clases y jerarquias, en este todo se confunde; en aquel el artesano pacífico, el sencillo labrador atendían a sus negocios respectivos sin ternor de ser atropellados; en éste temen a cada paso que experimentan el robo más escandaloso, la dilapidación, el vejamen, la violencia y el cuchillo asesino; en aquel éstos $\mathrm{y}$ todos los demás miembros de la sociedad vivían tranquilos bajo la salvaguardia de la ley, en éste no se conoce, no se observa más ley que el capricho de cuatro perdularios que se han investido del pomposo título de regeneradores de la sociedad. ¡Y con todo se atreven a decir que hemos hecho progresos en el camino de la ilustración! Dicen en el segundo miembro que la España ha salido del estado de opresión en que yacía. Y ¿cuál es ese estado de opresión en que la España yacía? consultad, fulleros, la historia de vuestra patria en los siglos que llamais del despotismo; vedla extender sus armas victoriosas por todo el mundo; vedla en disposición de dictar la ley a la Europa; ved, analizad uno por uno los sucesos de aquellos siglos; ved en cada Rey de aquellos a quienes calificais de déspotas un padre de sus vasallos, un protector de las artes y de los descubrimientos útiles a la sociedad, y decidnos ¿dónde está ese decantado despotismo? ${ }^{188}$.

Así pues, la contrarrevolución se justifica no sólo por la esencia perversa del régimen liberal, sino por que el cambio había sido ineficaz e innecesario.

\section{La construcción del mito personal de Cabrera}

Una de las características fundamentales de la prensa carlista es su condición dialéctica con los periódicos liberales. Páginas repletas de noticias copiadas de estos, glosas a muchos de sus artículos y contestaciones a través de los artículos de fondo, constituyen lo fundamental de ella. Tan atentos estaban a lo que de ellos se decía que reaccionaban con rapidez, y de manera compulsiva, a las criticas. También sucedía así cuando se producían invectivas contra las personas. Objeto habitual de ellas era el pretendiente don Carlos, como reflejaba una carta publicada en el Boletín...: «Muy Sr. mío: la fastidiosa repetición que he visto en los periódicos de Madrid de las voces, libertad, filantropía, derechos del ciudadano, de que tan poco uso hacen aquellos en su verdadero significado, como también la de las de despota, tirano, sanguinario, que tan caprichosa como injustamente aplican al más humano de los Reyes..." 189 . La prensa carlista contestaba edificando la figura de un rey ideal. Pieza a pieza don Carlos se presentaba como un monarca generoso, caritativo, justo, sensible y nada rencoroso:

...si puede llamarse despota a un REY que se priva de lo más preciso; porque nada falte a los valientes que lo defienden, a un REY que visita personalmente los hospitales consolando humanos, y socorriendo generoso a los que han ver-

188 «Sr. Redactor del Boletín de estos Reinos». Boletín de Aragón, Valencia y Murcia, núm. 43, 1 de agosto de 1839.

189 Boletín de Aragón, Valencia y Murcia, núm. 14, 21 de mayo de 1839. 
tido la sangre por su causa; a un REY que se desvela por guardar la equidad, procurando que su ejercito no dé motivo a reclamaciones; decidme, si cuadra el dictado de tirano y sanguinario a un REY que siente y se aflige cuando derramada la sangre de sus enemigos, tanto como cuando ve la de sus defensores; a un REY que perdona y olvida sus injurias personales... ${ }^{190}$.

Sin embargo, las circunstancias particulares en las que Aragón vivió la guerra determinaron que la construcción de una imagen idealizada de don Carlos no revistiera mucha urgencia. Fue en su defecto la necesidad de consolidar a Cabrera como jefe, la que acaparó la mayor parte de la atención para crear en torno a el una aureola mítica que, salvando las distancias, puede ser comparable con la que en otros lugares recibio el pretendiente.

Cabrera fue presentado como un joven de extracción humilde que habia ascendido de modo fulgurante merced a su naturaleza excepcional. Al hablar de él se referían a «un joven, apenas conocido hace cuatro años en el corto distrito del Corregimiento de Tortosa, sin relaciones, sin más alcurnia que su esforzado corazón y su pujante brazo, sin otra recomendación que su espada, y sus repetidos y gloriosos triunfos contra ejércitos...» ${ }^{191}$. Austeridad y sencillez se unen para perfilar un retrato dulce. ¿No encantas a los pueblos enteros con tu modesta sencillez; con tu desinteresado porte, con tu trato dulce, cortés y afable?» ${ }^{192}$. Una pincelada de amargura se trazaba con el antecedente del fusilamiento de su madre, añadiendo el matiz de general agraviado por la injusticia. Refiriéndose a Nogueras, se decía que estaba rehuyendo el momento "que el asesino de la madre de Cabrera se exponga a medir su espada con este joven general más valiente que él, y tan justamente exasperado» ${ }^{193}$. Y para redondear la estampa era preciso que incorporara también un componente religioso. Cabrera como católico ejemplar, como cruzado que hace una pausa en sus batallas para cumplir con sus obligaciones religiosas, se muestra sobre el decorado de Morella:

Hace tres días que tuvimos la satisfacción (siempre nueva para estos habitantes) de ver entrar en la plaza el ilustre Conde, que la salvó con su valiente espada [...] ha aprovechado estos momentos para cumplir con la obligación cristiana del precepto pascual, que no le habian permitido las serias atenciones de Segura, y lo verificó el día 27 de este mes en la parroquia castrense de San Miguel, confesando y comulgando con todo su estado mayor y con edificación de este vecindario. En la misma mañana dio otro ejemplo de piedad, tomando una parte muy principal en un consuelo que en esta plaza acaba de recibir la Iglesia.

Juan Serff, natural de Neumilsof a dos leguas de Stralsund, de religión luterano, hacía tiempo que impresionado fuertemente de la majestad del culto romano, le comparaba a menudo con la estéril frialdad del de su comunión. Las nobles heri-

\footnotetext{
190 Ibidem.

191 Boletín del Real Ejército de Aragón, 29 de mayo de 1837.

192 Boletín del Real Ejército de Aragón, 29 de mayo de 1837.

193 Boletín del Ejército Real de Aragón, Valencia y Murcia, núm. 91, 6 de dicjembre de 1837.
}

Hispania, LVIl/1, núm. 195 (1997) 213-265 
das que este bravo alemán recibió en la gloriosa defensa de Morella, le han proporcionado comodidad para ocuparse seria y detenidamente en este negocio interesante dando por resultado una sincera conversión a la religión católica ${ }^{194}$.

Próximo al milagro, el escritor contuvo su pluma resolviendo la escena en una simple conversión.

Abundando en esta faceta pía de Cabrera no puede olvidarse su función al servicio del providencialismo carlista. Providencialismo que sitúa a Cabrera directamente bajo la protección divina. «La mano del Señor nos ha manifestado de un modo maravilloso la decidida protección que dispensa personalmente al gran Cabrera» ${ }^{195}$. Pero también que coloca a Cabrera como instrumento de Dios en la Tierra. «Cabrera y los suyos en el nombre del Seffor, por esto y no por nulidad aquellos han caído y han sido vencidos y nosotros nos hemos animado y triunfado. [...] Dios, así como se valió de Moisés para sacar a su pueblo de la esclavitud del Faraón, de David para triunfar de Goliat, y de Judit para acabar con Holofernes, se ha valido del joven Cabrera para humillar a estos Faraones revolucionarios: ésta es la verdadera nulidad y mala intención de Oráa y los suyos, nosotros así lo confesamos y esto nos hace exclamar con Moisés ¿Quién es semejante a tí, Señor entre los fuertes?» ${ }^{196}$. Así, el fracaso del asalto liberal sobre Morella fue presentado como el resultado de la intervención divina, tal y como había sido reclamado con anterioridad: "Dios eterno! No permitais que se envanezcan nuestros enemigos con vuestras obras, y canten el triunfo sobre las ruinas de vuestro pueblo, sobre esta porción escogida que lo abandona todo por conservar ilesa su sacrosanta Religión atacada abiertamente y con furor por los impios demagogos de nuestros días ${ }^{397}$.

El propio Cabrera fue consciente de la necesidad que tenía de aprovechar todo el impulso que su admirada imagen podía proporcionarle y la alimento. Después de dictar una orden sobre el tratamiento que debían recibir los prisioneros se manifestaba en estos términos: «Lo hago saber al público, para que se desengañe algún iluso si queda, que así como a nadie cedo en contrarrestar crueldades, también he dado ejemplos de humano, como el presente» ${ }^{198}$. $\mathrm{E}$ incluso dejaba entrever que en el desarrollo de los hechos la imagen de las cosas resultaba decisiva ya que muchas de las críticas recibidas procedian de uuna falsa política y refinada perfidia [que] os la han hecho ver bajo otro punto de vista" ${ }^{199}$. Por ello la batalla más importante librada por la prensa contrarrevolucionaria en torno al mito de Cabrera fue tratando de alejar las

\footnotetext{
194 «Artículo de oficio. Morella 30 de abril». Boletín de Aragón, Valencia y Murcia, núm. 9, 9 de mayo de 1839.

195 Boletín del Ejército Real de los Reynos Unidos Aragón, Valencia y Murcia, núm. 43, 17 de junio de 1837.

196 Boletín de Aragón, Valencia y Murcia, núm. 20,6 de junio de 1839.

197 Boletín del Ejército Real de los Reynos Unidos Aragón, Valencia y Murcia, núm. 43, 17 de junio de 1837.

198 Valderrobres 4 de marzo de 1837, Boletín del Real Ejército de Aragón, núm. 30, 8 de marzo de 1837.

199 lbídem.
} 
imputaciones de ser un sangriento partidario de la violencia. La estrategia a seguir fue, ya que no era posible negarla, mostrar que se trataba de violencia justificada, nunca innecesaria. Sobre el fusilamiento de 16 urbanos del fuerte de Cava en represalia por el fusilamiento de Vicente Perciba en Peñíscola se decía: «No es pues el General Cabrera el asesino de los 16 urbanos fusilados, sino el inhumano Gobernador de Peñíscola. Contra su barbarie debemos levantar el grito cuantos nos compadecemos de la infeliz suerte de aquellos desgraciados" ${ }^{200}$. Ofreciendo el rostro de un general humano y sensible se pensaba excluir la posibilidad de que al mismo tiempo cupieran en él los crímenes de los que se le acusaba:

Solamente la calumnia, la mentira y mala fe pueden acusar a Cabrera de feroz y sanguinario. Es verdad, que con su valor e intrepidez parece un león cuando se halla en los combates; pero adornado siempre de aquellas nobles virtudes que moderan el rigor militar, la clemencia y compasión. En el trato familiar es un cordero, tal vez demasiado condescendiente; cito por testigos a cuantos por su empleo tienen que hablarfe con frecuencia; ellos dirán a la faz del mundo cuan sensible es Cabrera a los infortunios humanos, y que han visto muchas veces regarse sus mejillas con lágrimas tiernas, las que nunca vierten los hombres duros y feroces ${ }^{201}$.

$\mathrm{Y}$ abandonando el argumento de la violencia justificada se entró en una recreación libre de las atrocidades liberales para mostrar después una imagen cándida y tierna de Cabrera. Un doble juego de perspectivas digno de un buen productor publicitario. La imagen bárbara del liberalismo:

Un furor rabioso se ha apoderado de su alma, y como sino fueran bastantes las innumerables victimas que por más de cinco años han sacrificado al horrible título de sus funestas teorías, se está ejecutando en este momento una proscripción y matanza general. Los desgraciados prisioneros y los presos por opiniones políticas caen en mil puntos bajo la cuchilla de la revolución; los españoles pacíficos que algo tienen, son hacinados en las cárceles para ser despojados de su propiedad, o rescatar la vida a costa de sacrificios que les es imposible hacer; y los parientes de cualquier edad y sexo, de los que defienden a su legitimo Soberano y leyes patrias, vagan errantes, precisados a buscar otro domicilio, donde si no encontraran el sustento que su industria y la clemencia ajena les proporcionaba, es seguro que no les faltará un esbirro, encargado de criminar sus acciones para hacerlos dar un paso más en el camino de la tribulación ¡Las madres también y sus inocentes hijuelos son arrancados de sus hogares, y vagando por los campos sin saber a donde dirigirse, vuelven al Cielo sus ojos llorosos para buscar el consuelo de una aflicción que no merecen! ¡Hombres verdaderamente malvados! ${ }^{202}$.

200 «Represalias», Boletín del Ejército Real de Aragón, Valencia y Murcia, núm. 60, 17 de agosto de 1837.

201 «Su excelencia el conde de Morella pintado al natural; retrato original que debe contraponerse a los feos delineamientos con los que lo ha dibujado un infiel retratista, El Castellano, del 2 del actual», Boletín del Ejército Real de Aragón, Valencia y Murcia, 24 de noviembre de 1838.

202 «Represalias», Boletín del Ejénito Real de Aragón, Valencia y Murcia, 15 de diciembre de 1838.

Hispuniat, LVIJ/1, núm. 195 (1997) 213-265 


\section{El contraste humano y solidario:}

[Cabrera] pasó a visitar a los enfermos del Santo Hospital Militar de esta plaza en compañía de su gobernador y demás comitiva, y cama por cama les fue preguntando a cada uno, como se hallaban y si les faltaba la asistencia tanto a los fieles vasallos, como a los prisioneros que se hallaban en él. [...] Vengan ahora y siempre esos charlatanes y perpetuos detractores, los que todo lo vuelven del revés sentimientos, costumbres y lenguaje, porque a todos quisieran derrumbar por los mismos precipicios [...] suspendido el cuidado de sus huestes, depuesta su terribilidad belicosa, pospuestos los lauros tan justamente adquiridos sobre los desolladores del linaje humano; revestido de la mansedumbre y apacibilidad de cordero se entra por las mansiones del dolor y de los gemidos, y piadoso Samaritano les derrama en sus llagas el precioso bálsamo de la consolación y esmerada asistencia ${ }^{203}$.

Lo cierto, y eso no puede cuestionarse es que, se debiera a sus indudables dotes personales o a los efectos de una continuada campaña de elaboración del personaje, Cabrera paseó por los campos de batalla de Aragón y Valencia, ante los ojos admirados de sus soldados y temerosos de sus enemigos, una aureola mítica que ha perdurado en el tiempo. La figura histórica de Cabrera está todavía pendiente de una revisión seria, bien documentada y rigurosa, que parta desde una concepción amplia de su personalidad para comprender las claves de su biografía, personales, políticas, ideológicas, e incluso militares si es necesario, pero que acabe con las pobres reelaboraciones de la historiografía clásica del siglo XIX sobre el personaje ${ }^{204}$.

\section{Recrear la historia, explicar el pasado}

La contrarrevolución produjo una ideología que defendía y elogiaba las virtudes de la Religión y la Monarquía como pilares fundamentales del Estado, combatía, e infamaba, al liberalismo y a sus artífices y construyó para Cabrera la imagen de un general, justo y humano a través del cual se materializaba la voluntad divina. Para que el cuadro fuera completo faltaba un elemento: la reelaboración histórica del pasado que justificara como fueron abatidos el Altar y el Trono de la preeminencia que gozaban en el Antiguo Régimen a manos de una conspiración liberal y cómo el carlismo, cuyo rostro visible era Cabrera, llegaba para acabar con los efectos perniciosos de la revolución y devolver la situación a su equilibrio inicial. La historia tuvo en la ideología carlista un papel fundamental pues se hallaban en ella las claves de la acción presente. Explicando el proceso de encumbramiento revolucionario se obtendrían los elementos necesarios para justificar la contrarrevolución.

203 Recientemente hemos iniciado esta labor en Rúsula, Pedro, Ramón Cabrera. La senda del tigre, Ibercaja, Zaragoza, 1996.

204 Boletín del Ejército Real de Aragón, Valencia y Murcia, 15 de diciembre de 1838.

Hispariat, LVl1/1, nưm. 195 (1997) 213-265 
En sus propios términos, con referencia a la historia, "es preciso que registremos la llaga hasta lo más hondo si deseamos sanarla” ${ }^{205}$.

Como no podía ser de otra manera, el recorrido histórico comienza comparando la grandeza de los tiempos imperiales con la época de la guerra civil. "iQue contraste tan humillante para nosotros harán las historias del siglo XvI, tan gloriosas para la España, con los anales de ignominia el siglo XIX" 206 . La historia argumenta a su favor. «Lee, examina con imparcialidad la historia de España en los siglos quince, diez y seis y diez y siete... y dinos ingenuamente, si eres susceptible de esa ingenuidad, ¿en qué consiste el despotismo y tiranía de aquellos siglos y sobre qué bases estriba el nuevo orden de cosas que pretendeis establecer, y la felicidad que éste nos ha producido?" ${ }^{207}$. Partiendo pues de una situación óptima la pendiente de decadencia a la que abocaron la ilustración primèro y la revolución después resulta evidente:

\begin{abstract}
...se trató pues de ir desmoralizando lentamente para después descatolizarlo más fácilmente; se alucinó a la clase labradora, persuadiéndola o queriéndola persuadir que el diezmo no es de derecho Divino; al artesano se le quiso hacer creer que los bienes de las iglesias, la rentas de las dignidades y canongías eran supérfluas y sólo servían para enriquecer a unos cuantos holgazanes; a éstos y a todos los demás miembros de la sociedad se les pintaron los institutos religiosos como cosa inútil, y sus dignos individuos como unos zánganos ociosos, y aún perjudiciales al Estado, idea que por desgracia ha conocido bastante, y con algún fundamento recelamos tenga sus secuaces, no sólo en los ilustradisimos partidarios del gobierno liberal, sino aún entre algunos que se precian de súbditos de un Rey católico por excelencia; no decimos que los frailes son la Religión, ni que quitados éstos, se acabe en el mundo la idea de un Dios, pero sí aseguraremos, que dado el golpe a los institutos religiosos se está muy cerca de dárselo a la Religión católica; así ha sucedido en España luego que cuatro perdularios sin casa ni hogar se invistieron así mismo en Cádiz del título de soberanos, despojando al Monarca de sus atribuciones, concibieron y dieron a luz aquel código infernal que bajo el título de constitución política de la Monarquía española, debía dar al traves con nuestras antiguas instituciones ${ }^{208}$.
\end{abstract}

El proceso no fue único, sino que en otros momentos se apreciaron en Europa signos inequívocos de la misma degradación:

Dejaremos aparte hacer mención de las horrorosas escenas que presentó la Inglaterra con las llamadas reformas que introdujo en ella el sistema comenzado por Enrique VIII y continuado por su hija Isabel y por los Gremueres y Cramueles; no recordaremos los ataques que se dieron a la Religión, sus ministros, su culto, sus ceremonias y sus dogmas por el Rey filósofo de Prusia, por el blas:

205 Boletín del Ejército Real de Aragón, Valencia y Murcia, núm. 100, 6 de enero de 1838.

206 «Males incalculables que la impiedad revolucionaria ha causado a la España», Boletín del Ejército Real de Aragón, Valencia y Murcia, núm. 100, 6 de enero de 1838.

207 «Concluye el articulo inserto en el próximo número», Boletín de Aragón, Valencia y Murcia, núm. 44, 2 de agosto de 1839.

${ }^{20 k}$ Boletín de Aragón, Valencia y Murcia, núm. 53, 27 de agosto de 1839.

Hispania, LVLL/1, nu்m. 195 (1997) 213-265 
femo Voltaire, por el ginebrino Juan Jacobo; apartaremos la vista de los escandalosos sacrílegos cometidos en Francia por los jacobinos y convencionistas durante su sangrienta revolución a fines del siglo pasado, porque para recordar todo esto, era preciso escribir un volumen en folio ${ }^{209}$.

La ignorancia permitió que las ideas de los filósofos progresaran aunque siempre existieron paladines de la cristiandad que, como el padre Alvarado, pusieron su inteligencia y su fe al servicio de la verdad desprovista de artificio:

iAy del alcazar que al error fundaron la estúpida ignorancia y tirania! En lo mismo se han empleado tantos escritores pedantes como ha vomitado el infierno en nuestros días; no ha sido otro el objeto que se ha propuesto el Citador, el Diccionario Crítico burlesco, las ruinas de Palmira, el barón de Holbach, el juicio histórico-canónico de derecho de las naciones en Ios bienes de la Iglesia, y otros cuya enumeración verfa muy prolija, y a cuya refutación se han dedicado muchos verdaderos sabios, entre otros el piadoso y docto padre Alvarado en sus inmortales cartas llamadas del Filósofo Rancio ${ }^{210}$.

Fue una circunstancia involuntaria y violenta, la "cautividad" de Fernando VII seguida de la invasión francesa, la que permitió el acceso al poder de la revolución. «La cautividad de Fernando en 1808 y la guerra que a ella se siguió, fue la ocasión primera que se ofreció a esos hombres para alzar sus ominosas cabezas. Desde entonces se les ve sin intermisión afanarse por rivalizar con los hombres que en los años de 89 a 93 inundaron en sangre la nación vecina, empezando por copiar y adoptar para España el nefando código que aquellos promulgaron ¿Qué maldad podrá sorprendernos en estas gentes?" 211. Durante la guerra de la independencia, los Españoles lucharon por Dios y por el Rey y juntos consiguieron la expulsión del invasor, luego la guerra civil carlista que les ocupaba, ya que la revolución trataba de acabar con la Religion y destronar a un príncipe católico, se hacía por unos pocos contra los auténticos intereses de la nación.

[España] fue la primera y por entonces la única en declararse contra el tirano, sacudiendo finalmente el yugo que aquel querfa imponerle y admirando con sut importancia al mundo entero pero todos estos triunfos eran efecto de su unión. porque si exceptuamos unos pocos hijos espúreos de esta heroica nación que se

$209 \mathrm{Ibidem}$. En este, como en otros casos, la transcripción de los nombres es prácticamente irreconocible, lo que indica que, generalmente, no conocían su transcripción sino que habian sido escudchados en sermones y tertulias, lo que da una imagen del nivel cultural estandar del clero y, por extensión, del clero carlista. Cramueles es como suela Comwelles, que es lo que querían escribir. En otras ocasiones, siempre hque hemos reconocido la intencionalidad del autor, hemos reconstruido el nombre correctamente.

210 "Concluye el artículo inserto en el próximo númerow, Boletín de Aragón, Valencia y Mur. cia, núm. 44, 2 de agosto de 1839.

211 «La Redacción», firmado A.A.C., Boletín de Aragón, Valencia y Murcia, núm. 38, 18 de julio de 1839 .

Hispania, LVH'/, nưm. 195 (1997) 213-265 
alistaron a las banderas del tirano, la generalidad de los Españoles no conocía más divisa que DIOS y el REY; mas ahora en esta atroz guerra que se ha abierto, se trata nada menos que de si España ha de ser Católica o Atea; se trata de despojar del trono a un príncipe religioso, cuyo derecho es indisputable, y de colocar en él una niña titulada reina, a cuya sombra pudieran los agentes de esta farsa cometer los mayores excesos; se trata de entronizar la falsamente dicha libertad, pero que en los efectos ha de ser la más intolerable esclavitud; y para conseguirlo, aquellos mismos que pocos años antes habian declarado a su Rey inepto e incapaz de gobernar, valiéndose del mal estado de salud en que éste se hallaba, y de la juventud y poca previsión de la reina su esposa, toman las,riendas del gobierno, y se empeñan en hacer valer los supuestos derechos de la hija mayor del moribundo Fernando 212 .

El éxito momentáneo de la revolución en 1820 trajo consigo un proceso insurreccional en favor de los legitimos derechos del rey Fernando VII, pero los principales protagonistas de éste fueron marginados y olvidados en favor de los propios constitucionales que habian violentado la autoridad del monarca. «Muchos de aquellos militares honrados que habían vertido su sangre en defensa de los legítimos derechos de Fernando, se vieron separados de sus cuerpos, tal vez para hacer lugar a otros que habían combatido contra el mismo Soberano: los oficiales más decididos por la causa del Rey, postergados en sus ascensos a los mismos que habían visto en las filas constitucionales; no pocos fueron perseguidos, y los de Cataluña presos y confinados. La policía que parecía carecer de vista para observar los ocultos manejos de los revolucionarios, era un lince para indagar y castigar las faltas más leves de los que merecían el concepto de realistas" ${ }^{213}$. Pero los voluntarios realistas, a pesar del trato injusto que habian recibido permanecieron fieles a los principios del Altar y el Trono. «El cuerpo de voluntarios realistas, que bien dirigido aseguraba al Rey en su trono, fue desatendido, para no decir despreciado" 214 . De modo que fue necesario que una conspiración provocase su caida en desgracia a los ojos del rey. «La propaganda jacobina que había resuelto volver a tiranizar la España y entronizarse de nuevo, conoció que nada podría adelantar mientras no diera al través con estos distinguidos cuerpos, y resuelta a valerse de todos los medios por reprobados que fueran para conseguir su fin, logr6 a fuerza de intrigas y aparentando por la causa del trono el interés que no tenía, hacerlos sospechosos en el ánimo del Rey" ${ }^{215}$. Perdieron así parte de su influencia los voluntarios realistas al ser alejados del poder y otro tanto operó la inteligencia siniestra sobre don Carlos, el hermano del rey. Los revolucionarios «conocían no podrían prevalecer, ni llevar adelante sus planes de destrucción, mientras no lograran remover dos poderosos obstáculos, que

\footnotetext{
212 "Continuación del artículo inserto en los dos últimos números», Boletín de Aragón, Valen. cia y Murcia, núm. 49, 17 de agosto de 1839.

213 Boletín del Ejército Real de Aragón, Valencia y Murcia, 10 de febrero de 1838.

214 lbídem.

215 "Continuación del articulo inserto en nuestro ultimo número", Boletín de Aragón, Valencia y Muria, núm. 48,13 de agosto de 1839.

Hispania, LVIL/1, núm. 195 (1997) 213-265
} 
constantemente se opondrían al logro de sus designios; tales eran, el primero el virtuoso vástago de la familia Real, el único estorbo para sus planes, el amable Carlos Marf́a IsIDRo, en quien veían debía recaer la corona, caso de morir su hermano el Rey Fernando sin sucesión varonil, y el segundo, los Voluntarios Realistas 216 .

Como se ve, la última fase del reinado de Fernando VII es clave para sustentar su interpretación historica ya que en ella culmina la traición que llevará al trono a una regencia usurpadora en detrimento del legítimo rey.

La declinante salud y la atisbada muerte del último monarca hicieron incidir a la nación en la preparada sorpresa. Un puñado de criminales cortesanos, ansiosos de compilar fortunas inmensas a favor de revueltas políticas, $\mathrm{y}$ aún por entre piras de cadáveres, reuniendo en su apoyo una turba de grandes indignos de su alta posición, de consejeros sin probidad, y de militares sin honor previeron ese fallecimiento y proyectaron la mejor manera de explotar la nación en los momentos en que se verificase. No eran hombres que se arredrasen de acometer las más colosales perfidias, pero temblaban porque necesitaban sorprender a una nación esencialmente religiosa, fiel a sus soberanos y amante de la justicia, y que por consiguiente les haría pagar su crimen en el momento que llegase a conocerlos. Lograron en fin realizar la sorpresa: la hija mayor de Fernando que serfa en su mano elegida para comodín, pero esto no podía bastarles; es demasiado evidente el derecho del Sr. D. CARLOS para que pudiesen tranquilizarse con la farsa de proclamación que representaron.

La filosofía, la ilustración, la prosperidad nacional y otras voces igualmente seductoras formaban el denso velo, que resolvieron tender sobre el rostro de los españoles para el mejor éxito de sus depredaciones ${ }^{217}$.

Es el momento cumbre de la teoría conspirativa de la historia desarrollada por el carlismo. Convergen aquí todas las trayectorias anteriores y, con el comienzo de la guerra civil, otras nuevas tienen origen en este momento, entre las que cabe destacar la concepción de la revolución contínua, ávida de radicalismo, que evoluciona sin final buscando un extremo permanentemente renovado. Así se exponía esta avidez histórica de la revolución:

...si fuésemos novicios en experimentar las oscilaciones del partido liberal; lo que hoy pertenece al progreso, mañana ya es retrógrado, y no es digno del siglo de la luces. Para llegar al despotismo cruel a que está sujeto todo hombre pacífico aunque no sea carlista declarado, se pasó por decretos llenos de blandura y cuasi súplicas exigiendo el desarme de los voluntarios realistas para garantizar la tranquilidad que se alteraba con el choque de dos partidos, que debían estar unidos. Se siguíó otro dándoles gracias por la sumisión a la voluntad de la llamada Gobernadora. Se separó de sus destinos a los que los tenían ganados a fuerza de trabajos y servicios. Se incautó a los que se sospechaba podían entorpecer la marcha de un sistema liberal. Y hemos venido a parar en degollar públi-

216 «El ejército Real de Aragón Valencia y Murcia en los años 33 y 34 y en los 38 y 39.», Boletín de Aragón, Valencia y Murcia, núm. 47, 10 de agosto de 1839.

217 «Continúa del anterion», Boletín de Aragón, Valencia y Murcia, núm. 8, 7 de mayo de 1839. 
camente, y por el solo desahogo patriotico, no sólo al paisano sino al pacífico eclesiástico, sin que le sirviese de asilo el retiro de su casa o claustro.

Para llegar al sistema constitucional pasamos por un estatuto hipócrita: por diferentes nomenclaturas en los jefes de ministerios y provincias; hasta que con la autoridad del pueblo se gritó Viva la Constitución.

Hablemos claros: asegurarán estos señores que mañana no les dará la gana de gritar: viva la República. Se les deberá creer sobre mi palabra. Más acreedor es un gitano ${ }^{218}$.

Finalmente, y a modo de conclusión didáctica, puede ofrecerse esta versión vulgarizada de la última fase de la argumentación histórica carlista extraida de un dialoge chusco entre un labriego y un cristino:

Labrador: Usted señor don Bruno habla mucho, y no dice pizca de verdad. Nuestro Rey es un Rey sabio, piadoso y enemigo de canallas por eso los liberales le hacen tan cruel guerra, por que saben, que con él no hay que gastar chanzas; que si tuviesen esperanzas de hacer con él lo que hacen con Cristina, nada se les daria que fuese Rey. Por eso hicieron la farsa del testamento del Rey Fernando, y nos han venido ahora con Isabel sEgUnDa, a quien los liberales pueden ver como a un dolor de tripas; pero como les hace al caso, venga Isabel. Después de la muerte de Fernando séptimo les convenía hacer creer que la España sería gobernada por las mismas leyes que hasta entonces sin variar ni una sola coma, después dijeron que querian gobernar según las leyes antiguas, y publicaron aquello que decían estorando o estatuto poco más o menos, luego quisieron la constitución del año 12, enseguida la del año 1837. Unos quieren república, los otros cámaras y lo demás que V. sabe; y todo esto para poder gobernar unos cuantos miserables, que mejor sería fuesen a cavar y tejer, como tendrían que tejer o cavar, sino fueran esos mismos disturbios que ellos mueven para robar al pobre pueblo que siempre tienen en boca. En cuanto a Religion ciertamente que lo de quemar conventos e iglesias, lo de asesinar capellanes y religiosos, lo de sacar las monjas de sus conventos dejándolas perecer de hambre, la de quitar los diezmos, y de vender y robar los bienes de la Iglesia, dejando en cueros a sus ministros para engordar unas docenas de tunantes y tunantas que después irán a Francia; lo de destruir, insultar y patear las santas imágenes, hasta las hostias consagradas, lo de fusilar al Santísimo Sacramento (que alabado sea para siempre), en una palabra lo de mofarse públicamente y escarnecer los misterios de nuestra santa Religión, no son por cierto unas grandes pruebas de ser los de su partido unos buenos cristianos ${ }^{219}$.

En suma, la contrarrevolución desarrolló un planteamiento histórico del proceso por medio del cual la revolución habra llegado al poder. Incapacitados para identificar las auténticas fuerzas que habian dinamizado la sociedad y la economía espafiolas hasta producir el hundimiento de la monarquía absoluta, sólo encontraron una explicación que no fuera la imposibilidad de

${ }^{218}$ Boletín del Ejército Real de los Reynos Unidos Aragón, Valencia y Murcia, núm. 42, 14 de junio de 1837 .

219 Boletín de Aragón, Valencia y Murcia, núm. 17, 28 de mayo de 1839.

Hispania, LVH/l, núm. 195 (1997) 213-265 
seguir manteniendo el poder sobre el binomio Iglesia/Monarquía: la conspiración. El carlismo fue, por lo tanto, un avanzado en desarrollar una visión paranoica de la historia en la que los motores del cambio eran situados en tramas organizadas y secretas amparadas por la traición, pues, de otro modo, nunca se hubiera producido una evolución que supusiera un alejamiento de los fundamentos considerados "tradicionales" del pais.

Pedro Rújula

Universidad de Zaragoza 